\title{
Accumulation of amyloid- $\beta$ by astrocytes result in enlarged endosomes and microvesicle-induced apoptosis of neurons
}

\author{
Sofia Söllvander ${ }^{1}$, Elisabeth Nikitidou', Robin Brolin', Linda Söderberg ${ }^{2}$, Dag Sehlin ${ }^{1}$, Lars Lannfelt ${ }^{1}$ \\ and Anna Erlandsson ${ }^{1 *}$
}

\begin{abstract}
Background: Despite the clear physical association between activated astrocytes and amyloid- $\beta$ (A $\beta$ ) plaques, the importance of astrocytes and their therapeutic potential in Alzheimer's disease remain elusive. Soluble A $\beta$ aggregates, such as protofibrils, have been suggested to be responsible for the widespread neuronal cell death in Alzheimer's disease, but the mechanisms behind this remain unclear. Moreover, ineffective degradation is of great interest when it comes to the development and progression of neurodegeneration. Based on our previous results that astrocytes are extremely slow in degrading phagocytosed material, we hypothesized that astrocytes may be an important player in these processes. Hence, the aim of this study was to clarify the role of astrocytes in clearance, spreading and neuronal toxicity of $A \beta$.
\end{abstract}

Results: To examine the role of astrocytes in $A \beta$ pathology, we added $A \beta$ protofibrils to a co-culture system of primary neurons and glia. Our data demonstrates that astrocytes rapidly engulf large amounts of A $\beta$ protofibrils, but then store, rather than degrade the ingested material. The incomplete digestion results in a high intracellular load of toxic, partly $\mathrm{N}$-terminally truncated $A \beta$ and severe lysosomal dysfunction. Moreover, secretion of microvesicles containing $N$-terminally truncated $A \beta$, induce apoptosis of cortical neurons.

Conclusions: Taken together, our results suggest that astrocytes play a central role in the progression of Alzheimer's disease, by accumulating and spreading toxic A $\beta$ species.

Keywords: Alzheimer's disease, Protofibrils, Glia, Phagocytosis, Degradation, Enlarged vacuole, Microvesicle

\section{Background}

Knowledge about the cellular mechanisms behind initiation and spreading of Alzheimer's disease (AD) is still very limited. Decades of research have focused on neuronal abnormalities in AD pathology, but recently more attention has been given to other cell types, including astrocytes [1]. Being the most abundant glial cell type in the nervous system, astrocytes are highly responsible for maintaining brain homeostasis [2]. Their functions include metabolic support of neurons, modification of synapse signaling, recycling of neurotransmittors, regulation of blood flow and contribution to the blood brain

\footnotetext{
* Correspondence: anna.erlandsson@pubcare.uu.se

${ }^{1}$ Department of Public Health \& Caring Sciences/Molecular Geriatrics, Rudbeck Laboratory, Uppsala University, SE-751 85 Uppsala, Sweden

Full list of author information is available at the end of the article
}

barrier [2, 3]. In addition, astrocytes respond to all pathological conditions through a process referred to as reactive astrogliosis, in which the astrocytes convert to an inflammatory state [4].

The amyloid cascade hypothesis suggests that amyloid- $\beta$ (A $\beta$ ) mis-metabolism is the main causative event in $A D$, from which all other neuropathological features emanate [5]. Due to its hydrophobic nature, $A \beta$ monomers will aggregate and form soluble aggregated species, which eventually deposit as senile plaques. A major concern with the amyloid cascade hypothesis is that the number of plaques does not correlate with the severity of dementia [6,7]. However, results from different research groups indicate that it is the presence of soluble $A \beta$ aggregates, such as oligomers and protofibrils, rather than the plaques that induces the widespread neuronal death [8-12]. Protofibrils 
have been shown to be the predominant species of soluble $\mathrm{A} \beta$ aggregates in both tg-ArcSwe mice and human $\mathrm{AD}$ brains $[13,14]$. Moreover, the levels of soluble A $\beta$ aggregates in cerebrospinal fluid (CSF) have been demonstrated to be elevated in $\mathrm{AD}$ patients compared to controls and to correlate with cognitive impairment [15-18].

There is compelling evidence that $A \beta$ pathology is closely associated with inflammation and reactive astrocytes and microglia are situated tightly around the plaques [19]. The formation of a glial capsule around the $\mathrm{A} \beta$ deposits may protect the surrounding brain tissue from toxic $A \beta$ species, but the astrocytes and microglia have also been shown to secrete cytokines and neurotoxic products that could induce neuronal degeneration [20]. Astrocytes effectively engulf dead cells, synapses and protein aggregates of $\mathrm{A} \beta$ and $\alpha$-synuclein [21-27]. Interestingly, astrocytes have been shown to be more efficient than microglia in taking up $A \beta$, particularly during the early stages of $\mathrm{AD}$ [28]. The fact that reactive astrocytes with high $A \beta$ load are frequently found in the $\mathrm{AD}$ brain further confirms the importance of astrocytes in A $\beta$ clearance [29]. Compared to macrophages, that start to digest phagocytosed cell corpses directly, our group has previously demonstrated that it takes almost two weeks for astrocytes to degrade ingested, dead cells [26]. The inefficient degradation of dead cells by astrocytes is at least partly due to long lasting actin-rings surrounding the phagosomes, physically inhibiting the phagosome-lysosome fusion [30]. It is known that a large phagocytic burden could also inhibit degradation in professional phagocytes, by prolonging the time actin surrounds the phagosome [31]. Further, the astrocytes express high levels of Rab27a, a protein that reduces the lysosome acidity [30].

Since the majority of the patients with sporadic AD do not have an increased $A \beta$ production, it has been suggested that the main cause of this form of the disease is instead insufficient lysosomal degradation [32, 33]. Moreover, it is known that patients with lysosomal storage disorders often develop neurodegenerative diseases, including $\mathrm{AD}$ and Parkinson's disease [32, 34]. Ineffective degradation of $\mathrm{A} \beta$ may lead to spreading of $\mathrm{AD}$ pathology, due to secretion of A $\beta$-containing vesicles [35]. We hypothesized that astrocytes, due to their ineffective digestion may be an important player in these processes and the aim with the present investigation was to elucidate the role of astrocytes in $A \beta_{42}$ protofibril clearance and toxicity. Our data demonstrates that astrocytes engulf large amounts of $A \beta_{42}$ protofibrils that are stored in the astrocytes for a long time, rather than being degraded. This intracellular accumulation causes severe endosomal/ lysosomal defects that probably reduce the degradation capacity of the astrocytes further. In addition, incomplete degradation of $A \beta_{42}$ protofibrils results in microvesicleinduced neurotoxicity. Taken together, our results indicate that slow degradation by astrocytes may be a key process in $A \beta$ pathology.

\section{Results \\ Astrocytes engulf large amounts of $A \beta_{42}$ protofibrils}

In order to investigate the uptake of $A \beta_{42}$ protofibrils by the major cell types in the brain, we performed experiments using co-cultures of cortical astrocytes, neurons and oligodendrocytes. The cell cultures were exposed to fluorescent HiLyte $^{\text {TM }}$ Fluor 555-labeled $A \beta_{42}\left(A \beta_{42}-555\right)$ protofibrils for $24 \mathrm{~h}$, fixed and stained with specific antibodies to Glial Fibrillary Acidic Protein (GFAP), $\beta$ III tubulin and 2',3'-Cyclicnucleotide 3'-phosphodiesterase (CNPase), to label astrocytes, neurons and oligodendrocytes, respectively. We found that astrocytes contained large amounts of $A \beta_{42}-$ 555 (Fig. 1a and Additional file 1), while almost no $\mathrm{A} \beta_{42^{-}}$ 555 could be detected in the neurons (Fig. 1b and Additional file 1). Interestingly, the $A \beta_{42}-555$ inclusions in the astrocytes frequently co-localized with condensed, terminal (TdT)-mediated dUTP-biotin (TUNEL) positive cell nuclei of dead cells that had also been engulfed by the glial cells (Fig. 1a and Additional file 2). Uptake of $\mathrm{A} \beta_{42}-555$ protofibrils was also noted in the oligodendrocytes (Fig. 1c). However, the approximate percentage of oligodendrocytes in the cultures is very low $(6 \% \pm 3)$, compared to the astrocytes $(75 \% \pm 8)$ and neurons $(25 \% \pm 8)$. To confirm that the $A \beta_{42}-555$ deposits were situated inside the astrocytes we used confocal microscopy. The 3Dimages clearly show that $\mathrm{A} \beta_{42}-555$ protofibrils were taken up and predominantly localized around condensed nuclei of dead cells inside the astrocytes (Fig. 1d and Additional file 3). It is important to remember that GFAP stains the cytoskeleton of the astrocyte, which only constitutes $15-$ $20 \%$ of the cell [36]. Hence, the whole astrocyte is much bigger than the GFAP staining and the $A \beta_{42}-555$ found close to the GFAP staining is most likely also situated inside the cell (Fig. 1d and Additional file 3).

To verify that the 555-label still bound to the $A \beta$ after the engulfment, parallel co-cultures were treated with unlabeled $A \beta_{42}$ protofibrils for $24 \mathrm{~h}$, fixed and stained with GFAP and four different $\mathrm{A} \beta$ antibodies; mAb1C3 and $6 \mathrm{E} 10$ (both binding to the N-terminus of $A \beta$ ), mAb158 (selective for $A \beta$ protofibrils) and a polyclonal $\mathrm{A} \beta_{42}$ antibody. All antibodies displayed similar staining pattern, as received with the $A \beta_{42}-555$ protofibrils, demonstrating that the 555-signal represents the presence of $\mathrm{A} \beta$ (Additional file 4 A-D). To exclude that the degradation of $A \beta_{42}$ protofibrils in astrocytes was influenced by the neurons present in the co-culture, we performed experiments with cell cultures differentiated in the presence of cilliary neurotrophic factor (CNTF). CNTF is known to drive E14 neural stem cells to generate almost exclusively astrocytes [37, 38]. The astrocytes in the CNTF-treated cultures were found to accumulate 

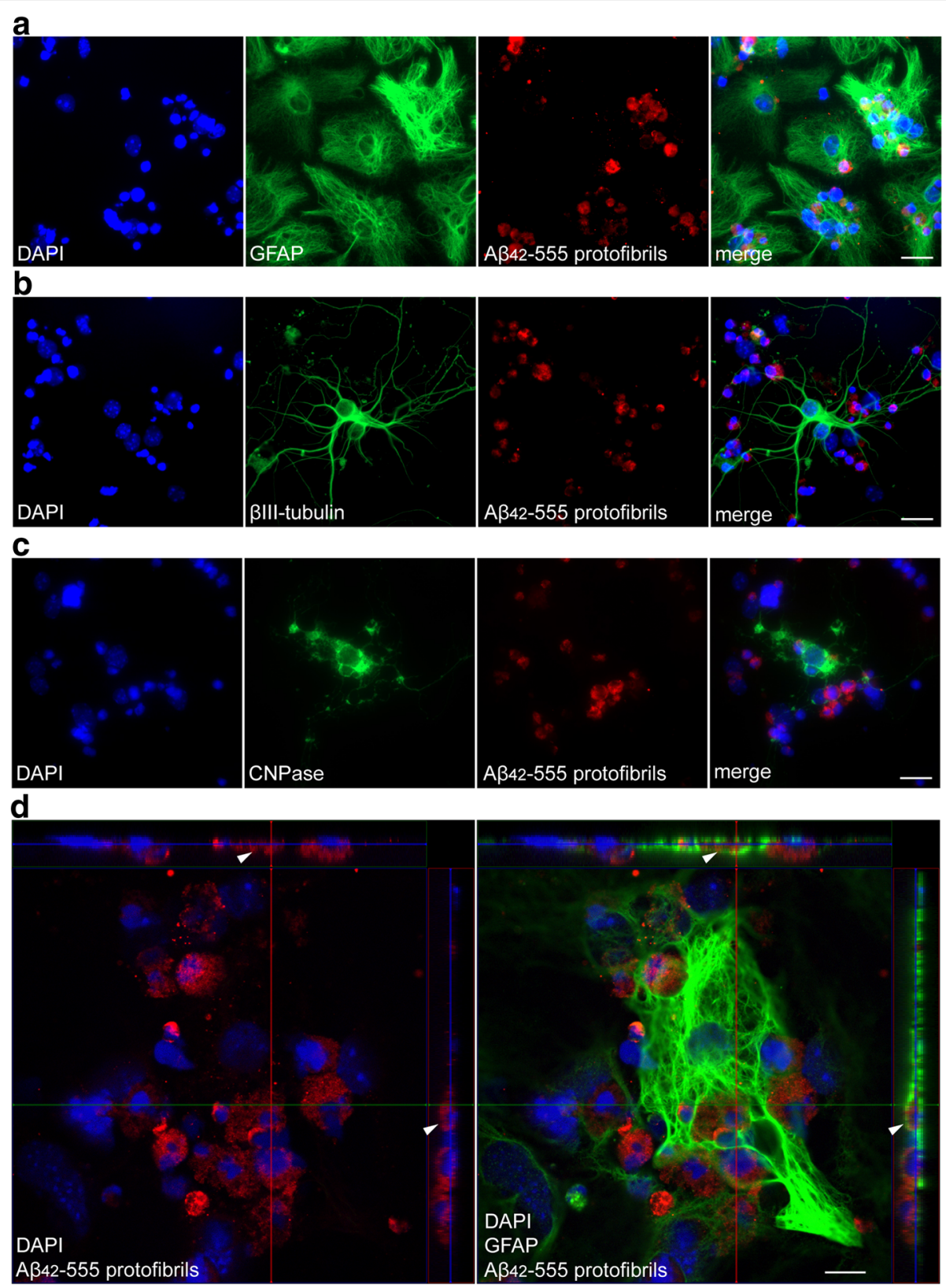

Fig. $1 \mathrm{~A} \beta_{42}$ protofibril deposits are found in glial cells, but not in neurons. Immunocytochemistry of co-cultures containing astrocytes, neurons and oligodendrocytes demonstrates that astrocytes contain large deposits of $A \beta_{42}-555$ (a). Neurons lack detectable $A \beta_{42}-555$ levels $(\mathbf{b})$, but the few oligodendrocytes in the culture also contain $A \beta_{42}-555$ (c). Confocal imaging confirms intracellular localization of large $A \beta_{42}-555$ inclusions in astrocytes (d). DAPI (blue), GFAP (green) and $A \beta_{42}-555$ (red). Scale bars: $\mathbf{a}-\mathbf{c}=20 \mu \mathrm{m}, \mathbf{d}=10 \mu \mathrm{m}$

$\mathrm{A} \beta_{42}$ protofibrils in a similar way to those in the cocultures (Additional file 5). To follow the engulfment of $\mathrm{A} \beta$ protofibrils over time we next performed time-lapse experiments, in which we recorded the cell culture during the $24 \mathrm{~h} \mathrm{~A} \beta_{42}-555$ protofibril exposure. Our timelapse movies demonstrate that already after $30 \mathrm{~min}$, astrocytes (identified by their phenotype of an egg "sunny side up", large nuclei and multi-vesicular cytoplasm) had accumulated $A \beta_{42}-555$, and the intensity of the staining constantly increased during the $24 \mathrm{~h}$ time period (Fig. 2a, b and Additional file 6). In line with our results from the immunostainings, very little of the $A \beta_{42}-555$ protofibrils co-localized with neurons (identified by their oval cell bodies, distinct axons and active migration) (Fig. 2a, c and Additional file 6).

The tg-ArcSwe mouse model is known to have elevated levels of soluble $A \beta$ aggregates including protofibrils, and $\mathrm{AD}$-like $\mathrm{A} \beta$ plaque pathology with an onset 


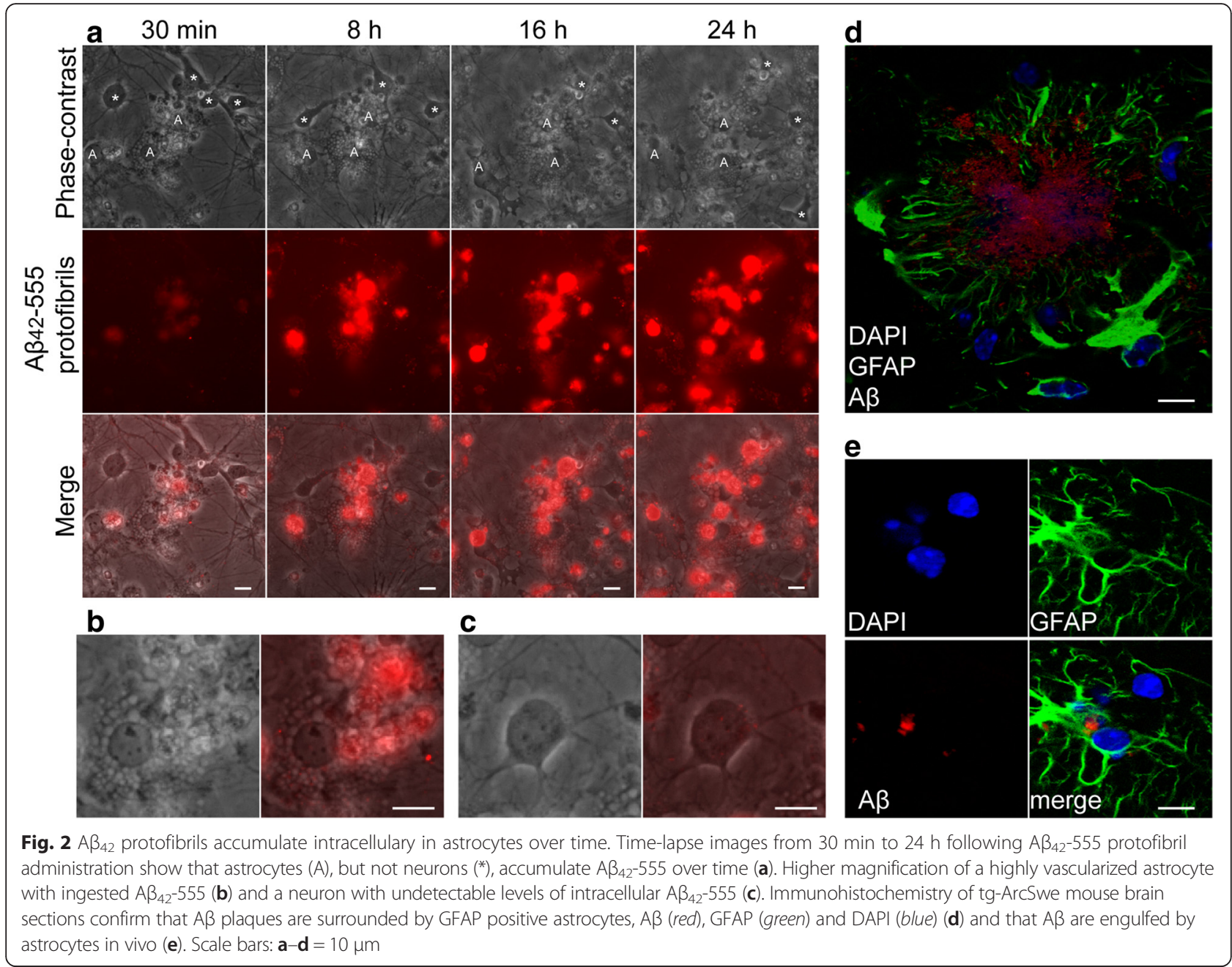

around six months of age [39-41]. Immunostainings of brain sections from 12 to 14-month-old tg-ArcSwe mice, using antibodies against GFAP and $\mathrm{A} \beta$ demonstrated that astrocytes, as expected, were tightly localized around $A \beta$ plaques (Fig. 2d) and that $A \beta$ co-localize with astrocytes in vivo (Additional file 7). Interestingly, we also found that some of the $A \beta$ that had been ingested by reactive astrocytes co-localized with condensed nuclei of dead cells, confirming that our findings in the cell cultures reflect cellular processes of $A \beta$ pathology in vivo (Fig. 2e).

\section{$A \beta$ protofibrils are accumulated in astrocytes for a very long time}

To follow the degradation of intracellular $A \beta_{42}$ protofibrils in astrocytes, neurons and oligodendrocytes, cell cultures were thoroughly washed after the $24 \mathrm{~h} \mathrm{~A} \beta_{42}-555$ protofibril exposure and cultured for additional 6 or 12 days prior to fixation and staining. The cells were divided into four categories; cells with no detectable levels of $A \beta_{42}-555(-)$, cells with only small amounts of
$A \beta_{42}-555(+)$, cells containing medium sized $A \beta_{42}-555$ inclusions or larger $A \beta_{42}-555$ inclusions with low intensity $(++)$ and cells with one or more large $A \beta_{42}-555$ inclusion with high intensity $(+++)$. The four categories in combination with GFAP staining are shown in Fig. 3a. Quantification of the percentage of astrocytes in each category demonstrates that most astrocytes contained large inclusions of $A \beta_{42^{2}}-555(+++)$ directly after the $24 \mathrm{~h}$ exposure $(63.5 \pm 20.1 \%)$. Although the percentage of $(+++)$ astrocytes had decreased significantly after 6 days $(30.7 \pm 24.0 \%, P<0.001)$ and 12 days $(33.8 \pm 15.3 \%$ $P<0.001)$, the degradation was extremely slow. The percentage of astrocytes containing medium sized $\mathrm{A} \beta_{42}-555$ inclusions $(++)$ was lower at $24 \mathrm{~h}(15.4 \pm 11.0 \%)$, but did not decrease over time. Astrocytes containing small amounts of $A \beta_{42}-555(+)$ and astrocytes with no detectable levels of $A \beta_{42}-555(-)$ increased significantly from $24 \mathrm{~h}(18.3 \pm 16 \%$ respective $2.6 \pm 4.6 \%)$ to $24 \mathrm{~h}+$ 6 days $(30.0 \pm 16.6 \%, P=0.0034$ respective $22.6 \pm 18.8 \%$, $P<0.001)$. Taken together, these results demonstrate that astrocytes effectively ingest $A \beta_{42}$ protofibrils, but that the 


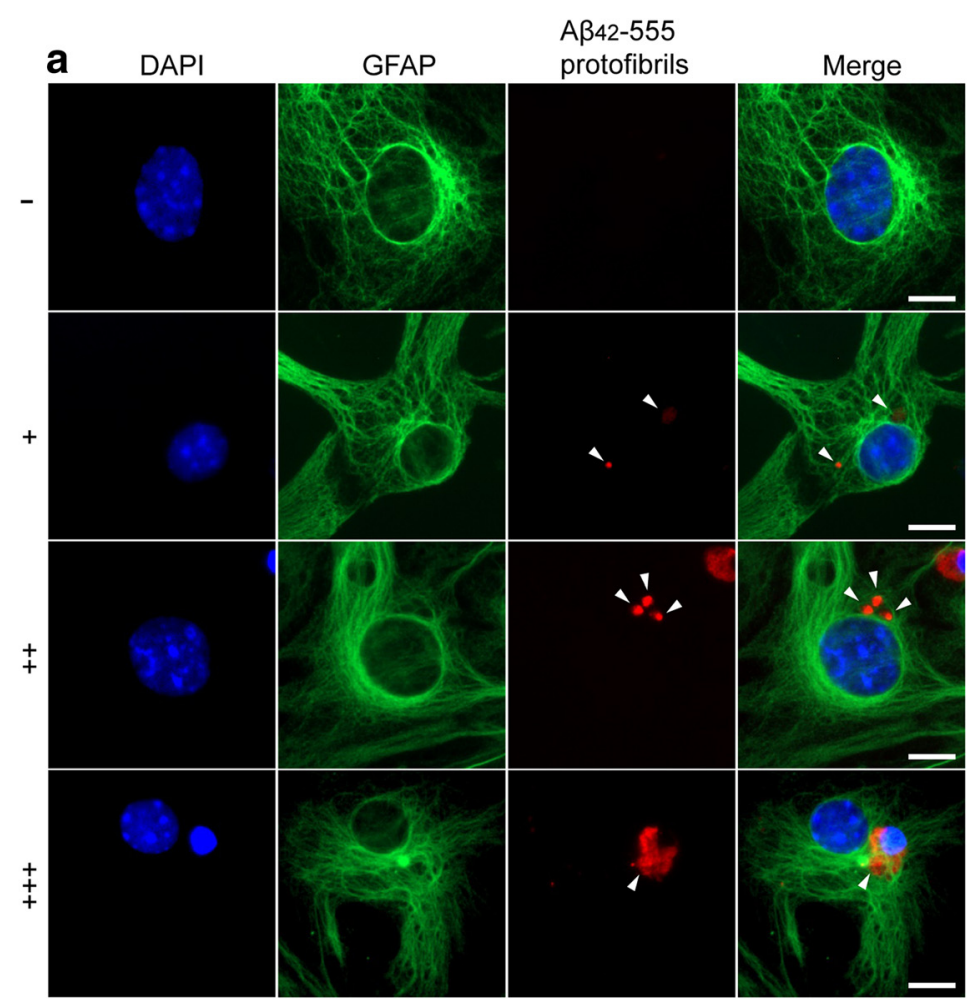

$$
\text { b }
$$

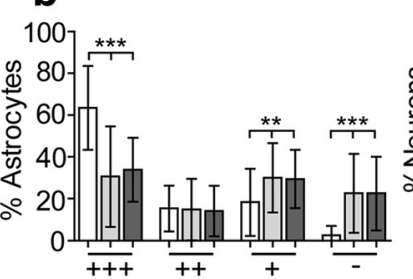

$\square 24 \mathrm{~h}$

प24 $\mathrm{h}+6$ days

$$
\square 24 \mathrm{~h}+12 \text { days }
$$

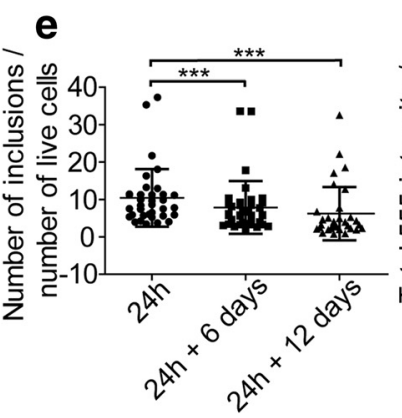

\section{C}

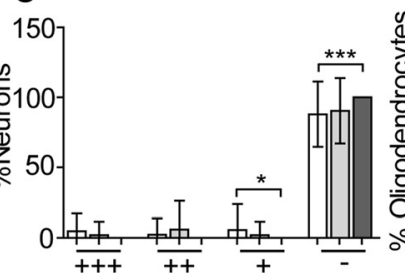

d

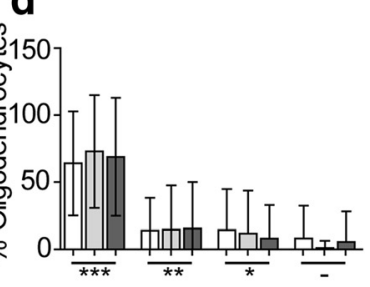

f

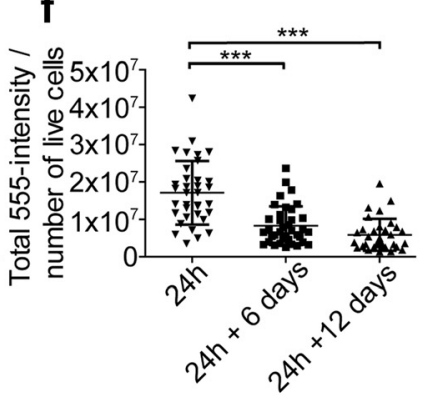

g

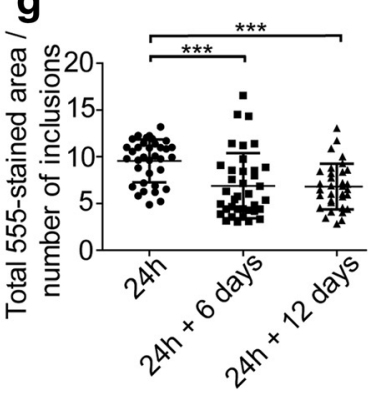

Fig. $3 A \beta_{42}$ are stored in astrocytes for a very long time. To follow degradation of intracellular $A \beta_{42}-555$ in astrocytes following $A \beta_{42}-555$ protofibril removal, cells were divided into four categories; cells with no detectable levels of $A \beta_{42}-555(-)$, cells with only small amounts of $A \beta_{42}-555$ $(+)$, cells containing medium sized $A \beta_{42}-555$ deposits (++) and cells with large $A \beta_{42}-555$ inclusions (+++) (a). Astrocytes degrade $A \beta_{42}-555$ protofibrils very slowly and much $A \beta_{42}$ remains in the cells 12 days after $A \beta_{42}-555$ protofibril removal (b). Neurons contain almost no $A \beta_{42}$ (c). The few oligodendrocytes in the culture also degrade the $A \beta_{42}-555$ protofibrils slowly (d). Although the glial cells degrade the $A \beta_{42}-555$ protofibrils slowly, the total number of 555 -stained inclusions ( $24 \mathrm{~h}: 10.4 \pm 7.7 ; 24 \mathrm{~h}+6$ days: $7.9 \pm 7.1 ; 24 \mathrm{~h}+12$ days: $6.2 \pm 7.1)$ in the culture decline significantly from $24 \mathrm{~h}$ to $24 \mathrm{~h}+6$ days $(P=0.013)$ and $24 \mathrm{~h}+12$ days $(P<0.001)$ (e). In line with these results, the total 555-intensity $\left(24 \mathrm{~h}: 1.7 \times 10^{7} \pm 8.5 \times 10^{6} ; 24 \mathrm{~h}+6\right.$ days: $8.3 \times 10^{6} \pm 5.1 \times 10^{6} ; 24 \mathrm{~h}+12$ days: $\left.5.9 \times 10^{6} \pm 4.3 \times 10^{6}\right)(\mathbf{f})$ and total 555 -positive area (24 h: $9.6 \pm 2.3 \mu \mathrm{m}^{2} ; 24 \mathrm{~h}+6$ days: $6.7 \pm 3.5 \mu \mathrm{m}^{2} ; 24 \mathrm{~h}+12$ days: $\left.6.8 \pm 2.5 \mu \mathrm{m}^{2}\right)(\mathbf{g})$ also decline significantly over time $(P<0.001$ already from $24 \mathrm{~h}$ to $24 \mathrm{~h}+6$ days). $A \beta$ inclusions are marked with white arrow heads. Scale bars: $10 \mu \mathrm{m}$. The experiments were performed in triplicates with independent cell cultures and 10 images/experiment were analyzed. Mann-Whitney $U$-test ${ }^{* * *} P<0.001$ 
ingested material is only partially degraded within 12 days (Fig. 3b). Neurons had low or no detectable $A \beta_{42}-555$ inclusions at $24 \mathrm{~h}$ (Fig. 3c) whereas most of the few oligodendrocytes in the culture contained large $(+++)$ or medium (++) $\mathrm{A} \beta_{42}-555$ inclusions that did not significantly change over time (Fig. 3d). As a complement, we next analyzed the total number of inclusions, total intensity and total area of $A \beta_{42}-555$ deposits (normalized to the total number of cells) in the cell culture, using the Zen 2012 software. The number of 555-stained inclusions, normalized to the number of live cell nuclei, declined significantly from $24 \mathrm{~h}$ to $24 \mathrm{~h}+6$ days $(P<0.001)$, indicating that the inclusions were either degraded or fused (Fig. 3e). The total 555-intensity (Fig. 3f) and total 555-positive area (Fig. $3 g)$ also declined significantly over time $(P<0.001$ already from $24 \mathrm{~h}$ to $24 \mathrm{~h}+6$ days), confirming that the astrocytes degrade the $A \beta_{42}-555$ protofibrils to some degree, although very slowly. In contrast to our results with $\mathrm{A} \beta_{42}-555$ protofibrils, cell cultures exposed to $A \beta_{40}-555$ monomers, showed no accumulation of $A \beta$ in astrocytes (Additional file 8).

\section{Engulfed $A \beta$ protofibrils co-localize with the lysosomal marker LAMP-1}

In order to investigate the intracellular localization of the $\mathrm{A} \beta$ deposits in astrocytes we next performed immunostainings with the lysosome specific antibody LAMP-1. Our results show that there was only little overlap between LAMP- 1 and $A \beta_{42}$ directly after the $A \beta_{42}$ protofibril exposure $(24 \mathrm{~h})$, but the co-localization increased over time and 12 days after $A \beta_{42}$ protofibril removal, most of the intracellular $A \beta_{42}$ deposits co-localized with LAMP-1 positive vesicles (Fig. 4a). These results demonstrate that the engulfed $A \beta_{42}$ protofibrils were transported to lysosomal compartments within the astrocytes. However, we have previously shown that engulfed dead cells in astrocytes can be present in LAMP-1 positive phagosomes/lysosomes without being degraded. The reason is insufficient acidification of astrocytic lysosomes resulting in inadequate digestion of the ingested material [26]. To clarify if the lysosomes in the $A \beta_{42}$ protofibril accumulating astrocytes were acidic or not, we performed experiments using LysoTracker, which is a dye that labels acidic organelles. We found that although being LAMP-1 positive, the $\mathrm{A} \beta_{42}$ containing lysosomes did not stain with the LysoTracker, indicating that $A \beta_{42}$ stored in the glial cells were situated in immature lysosomes (Fig. 4b). Interestingly, immunostainings of brain sections from 14-month-old tgArcSwe mice using specific antibodies against LAMP-2 and mAb158 (Fig. 4c) or GFAP and mAb158 (Fig. 4d) demonstrated that $\mathrm{A} \beta$ co-localized with both LAMP-2 and GFAP in vivo. It was the outermost layer of the $A \beta$ plaque, rather than the plaque core that was LAMP-2 positive, suggesting that the most superficial $A \beta$ could actually be situated in lysosomal compartments inside the glial cells that tightly surround the plaque (as GFAP only stains 15-20\% of the astrocytic cell bodies [36]).

\section{Intracellular stored $A \beta$ is truncated in the $\mathbf{N}$-terminus}

We next sought to investigate if the $A \beta_{42}$ stored in the immature lysosomes was partly degraded. For this purpose we analyzed cell culture lysates using three different sets of sandwich ELISAs; the N-terminus dependent $A \beta_{1-x}$ ELISA, the protofibril specific $\mathrm{mAb} 158$ ELISA and the N-terminus independent $A \beta_{x-42}$ ELISA. In the $A \beta_{1-x}$ ELISA, one of the antibodies is specific for the $\mathrm{N}$-terminal $\mathrm{A} \beta$ neo-epitope (82E1, raised against $A \beta_{1-16}$ ) and the other antibody binds to the central region of $A \beta$ (4G8, raised against $A \beta 17-24)$, measuring $A \beta_{42}$ with an intact $N$-terminal. In the $A \beta_{x-42}$ ELISA, one of the antibodies is specific for the C-terminal $\mathrm{A} \beta_{42}$ neo-epitope [42] and the other antibody binds to the central region of $A \beta$ (4G8), measuring both intact and $N$ terminally truncated forms of $A \beta$. Both the $A \beta_{1-x}$ ELISA and the mAb158 ELISA, showed a 3-fold decrease in $A \beta$ concentrations from $24 \mathrm{~h}$ to $24 \mathrm{~h}+6$ days $(P<0.001$ for both) (Fig. 5a, b). The $A \beta$ levels measured by the $A \beta_{1-x}$ ELISA decreased further and were halved at $24 \mathrm{~h}+12$ days compared to $24 \mathrm{~h}+6$ days $(P=0.0058)$ (Fig. 5a). In contrast, when analyzing the cell lysates using the $A \beta_{x-42}$ ELISA, the concentrations did not decrease during the first 6 days and there was only a 1.5 -fold decline from $24 \mathrm{~h}+$ 6 days to $24 \mathrm{~h}+12$ days $(P=0.036)$. Hence, the concentrations remained higher using the $\mathrm{A} \beta_{\mathrm{x}-42}$ ELISA compared to the $A \beta_{1-x}$ and mAb158 ELISA, indicating that a high proportion of the stored $A \beta$ is $N$-terminally truncated (Fig. $5 \mathrm{a}-\mathrm{c}$ ). Since our immunostainings demonstrated that the engulfed $A \beta$ often co-localized with condensed cell nuclei of dead cells that had also been ingested by the astrocytes (Fig. 1a), we performed additional analysis of the pellet (consisting of nuclei and cell debris) that remained after the cell lysis procedure. The pellets were treated with formic acid and sonication to extract $A \beta$ prior to analysis with the $A \beta_{1-x}$ ELISA and the $A \beta_{x-42}$ ELISA. Interestingly, we found that the pellet fraction from $24 \mathrm{~h}$, but also from $24 \mathrm{~h}+6$ days and $24 \mathrm{~h}+12$ days showed higher $\mathrm{A} \beta$ concentrations in the $A \beta_{x-42}$ ELISA compared to the $A \beta_{1-x}$ ELISA, indicating existence of N-terminally truncated $A \beta_{42}$ (Fig. 5d, e). Taken together, the results show that full length $\mathrm{A} \beta_{1-42}$ and $\mathrm{A} \beta_{42}$ protofibrils (Fig. 5a, b, d) decrease more over time than $\mathrm{N}$-terminally truncated forms of $\mathrm{A} \beta$ (Fig. 5c, e), indicating that the intracellular deposits of $\mathrm{A} \beta$ in astrocytes are processed by the astrocytes in a way that may change their properties and toxicity.

\section{$A \beta$ accumulation induces formation of giant astrocytic endosomes}

The cell cultures were followed for up to 5 days after the $\mathrm{A} \beta_{42}$ protofibril exposure, using time-lapse recordings. 

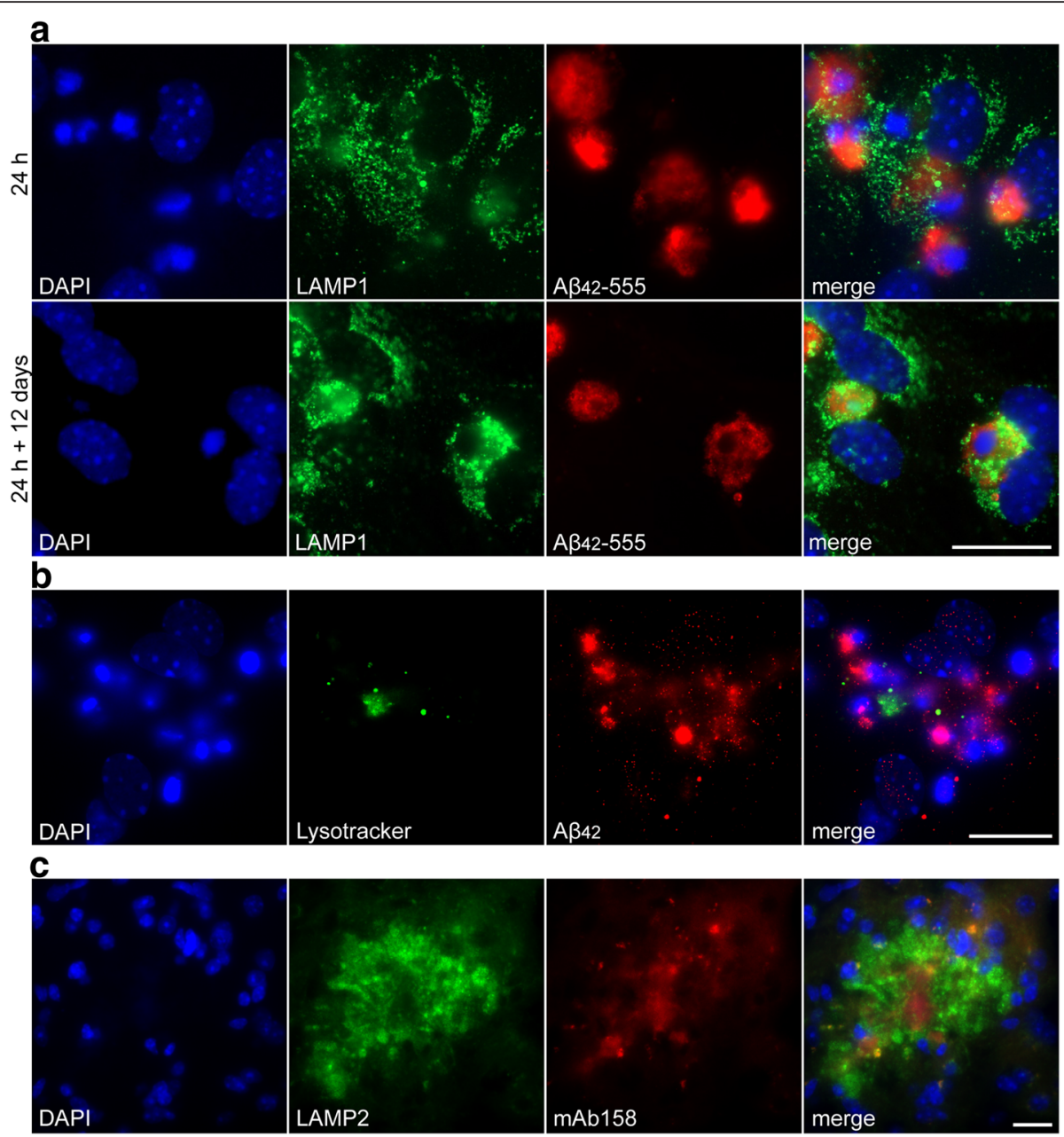

d

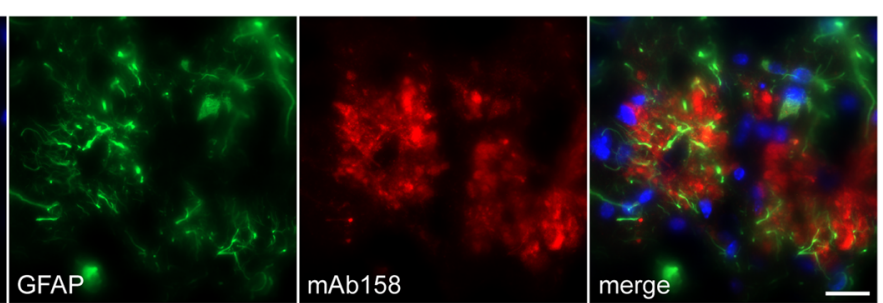

Fig. $4 A \beta_{42}$ accumulates in immature lysosomes. The co-localization of $A \beta_{42}$ and LAMP-1 positive lysosomes increases from $24 \mathrm{~h}$ to $24 \mathrm{~h}+12$ days (a). LysoTracker staining does not overlap with the $A \beta_{42}$ protofibril inclusions, demonstrating that the $A \beta_{42}$ containing lysosomes are immature (b). $A \beta_{42}$ protofibrils co-localize with LAMP-2 (c) and GFAP (d) in sections of 14-month-old tg-ArcSwe mice. Scale bars: a-d = $20 \mu \mathrm{m}$

Interestingly, we found that the accumulation of $A \beta_{42}$ protofibrils induced formation of enlarged, dynamic vacuoles in the astrocytes (Fig. 6a, and Additional file 9). The vacuoles increased rapidly in size, fused with adjacent vacuoles and resulted in giant vacuoles with a diameter of $\sim 50 \mu \mathrm{m}$ (Fig. 6b, and Additional file 10). The giant vacuoles eventually shrank or collapsed, but concurrently new vacuoles appeared in the same cell (Fig. 6a, and Additional file 9). The enlarged vacuoles were never found in control cultures, indicating that they are a direct result of the high $A \beta_{42}$ load in the astrocytes. Immunostainings of fixed, $A \beta_{42}$ protofibril exposed cell cultures, using specific antibodies to the early endosomal marker, Rab5, and the late endosomal marker, Rab7, demonstrated that the giant vacuoles are proposed to be derived from early endosomes (Fig. 6c). Moreover, double stainings with specific antibodies to $A \beta / \operatorname{Rab} 5$ and $A \beta / \operatorname{Rab7}$ (Additional file 11), showed a clear co-localization of $A \beta$ inclusions and Rab5. Some co-localization was also noted for $A \beta$ and Rab7. These data emphasize that accumulation of $A \beta_{42}$ protofibrils induces severe lysosome failure in the phagocytic 


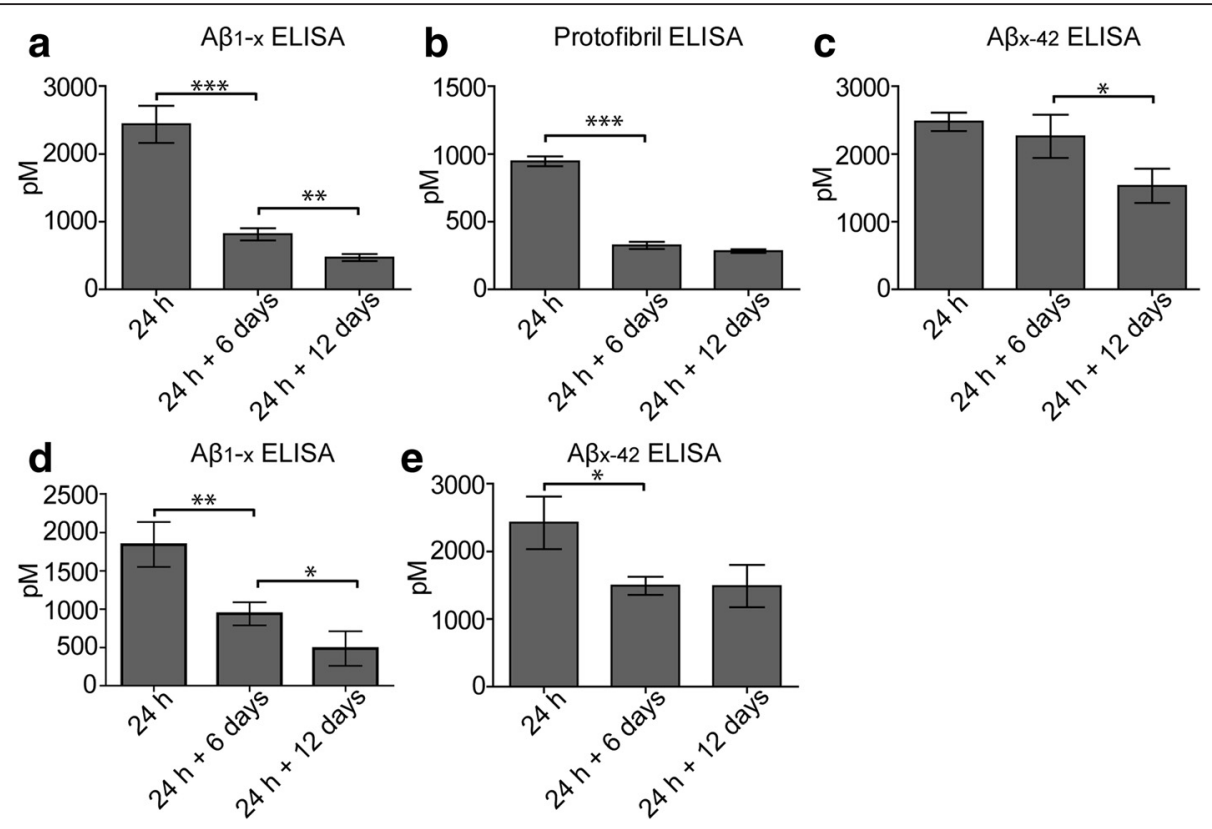

Fig. 5 Intracellular stored $A \beta_{42}$ is truncated in the N-terminus. A $\beta$ ELISAs of cell lysates from $24 \mathrm{~h}$ and from 6 to 12 days following $A \beta_{42}$ protofibril removal ( $24 \mathrm{~h}+6$ days and $24 \mathrm{~h}+12$ days, respectively) demonstrate that a high proportion of the accumulated $A \beta$ is $\mathrm{N}$-terminally truncated. The concentrations of $A \beta_{1-x}(\mathbf{a})$ and $A \beta$ protofibrils (b) decrease continuously from $24 \mathrm{~h}(2434.0 \pm 272.0$ and $946.9 \pm 36.5$, respectively) to $24 \mathrm{~h}+6$ days ( $862.8 \pm 92.0$ and $325.8 \pm 25.9$, respectively) and $24 \mathrm{~h}+12$ days (468.2 \pm 52.2 and $282.9 \pm 13.1$, respectively), while the concentrations of $A \beta_{x-42}$ remain higher over time ( $24 \mathrm{~h}: 2475.0 \pm 134.0,24 \mathrm{~h}+6$ days: $226.01 \pm 318.3$ and $24 \mathrm{~h}+12$ days: $1531.0 \pm 253.1)$ (c). In the pellets, remaining after the cell lysis procedure, the $A \beta_{1-x}$ concentrations decline over time ( $24 \mathrm{~h}: 1840.0 \pm 289.5,24 \mathrm{~h}+6$ days: $938.3 \pm 159.7,24 \mathrm{~h}+12$ days: $\left.483.3 \pm 225.3\right)$ (d), while the $A \beta_{x-42}$ concentrations are higher at $24 \mathrm{~h}(2422.0 \pm 387.0)$ and more stable over time, $24 \mathrm{~h}+6$ days (1493.0 \pm 132.7$)$ and $24 \mathrm{~h}+12$ days (1488.0 \pm 312.6$)$ (e). All concentrations are expressed in picomolar (pM) units. Mean values are from duplicates of three independent experiments

astrocytes. The collapsing vacuoles did not cause astrocytic cell death during the time-lapse experiment, but may induce the release of $A \beta$ containing microvesicles from the astrocytes.

\section{Engulfing astrocytes induce secondary $A \beta$ toxicity}

To further investigate how the $A \beta_{42}$ protofibril exposure affects viability of the three different cell types in the culture, we quantified the number of living astrocytes, neurons and oligodendrocytes directly after the $24 \mathrm{~h}$ $\mathrm{A} \beta_{42}$ protofibril exposure and 6 and 12 days after $A \beta_{42}$ protofibril removal. The total number of cells was compared to the cell number in parallel control cultures that did not receive any $A \beta_{42}$ protofibrils. A modest, but significant, increase in the cell number following $A \beta_{42}$ protofibril exposure was noted at $24 \mathrm{~h}+12$ days, for both astrocytes and oligodendrocytes $(P=0.011$ and $P<0.001$, respectively) (Fig. $7 a$ and $b$ ), indicating that the $A \beta_{42}$ protofibril clearing process induces some proliferation of the glial cells. In contrast, the number of neurons was decreasing over time in the $A \beta_{42}$ protofibril exposed cultures (Fig. $7 \mathrm{c}$ ). The fact that $A \beta_{42}$ protofibril exposure did not induce neuronal death directly, but the decrease in neuronal number appeared 12 days after $A \beta_{42}$ protofibril removal $(P=0.0061)$, indicates that the cell death is due to a secondary mechanism.
Neuronal cell death is induced by secreted microvesicles

To identify possible mechanisms for the secondary toxicity, we investigated if microvesicles secreted by $\mathrm{A} \beta_{42}$ protofibril treated co-cultures induce apoptosis of cortical neurons. For these experiments we exposed cocultures with $A \beta_{42}$ protofibrils for $24 \mathrm{~h}$, washed the cultures thoroughly and cultured the cells in $A \beta_{42}$ protofibril-free medium for additional 12 days. Parallel control cultures received medium only. Microvesicles were isolated using ultracentrifugation of conditioned medium harvested day 6 and 12 following $A \beta_{42}$ protofibril removal. The microvesicle pellets were reconstituted in neurobasal medium and added to embryonic cortical mouse neurons that had been cultured for 12 days (12 days in vitro). After $48 \mathrm{~h}$, the neurons were fixed and the number of apoptotic, TUNEL labeled neurons was compared (Fig. 8a). Studies of astrocytes using electron microscopy, demonstrated a release of microvesicles of different sizes (Fig. 8b). Moreover, electron microscopy analysis of the microvesicle preparations, identified microvesicles (>100 nm in diameter, Fig. $8 \mathrm{c}-\mathrm{d}$ ). Microvesicles, isolated from both untreated and $A \beta_{42}$ protofibril exposed cell cultures, expressed the microvesicle marker Flotillin-1. However, no differences in the total protein concentration of Flotillin-1 was detected between untreated and $A \beta_{42}$ protofibril exposed cell cultures (Fig. 8e). Interestingly, 

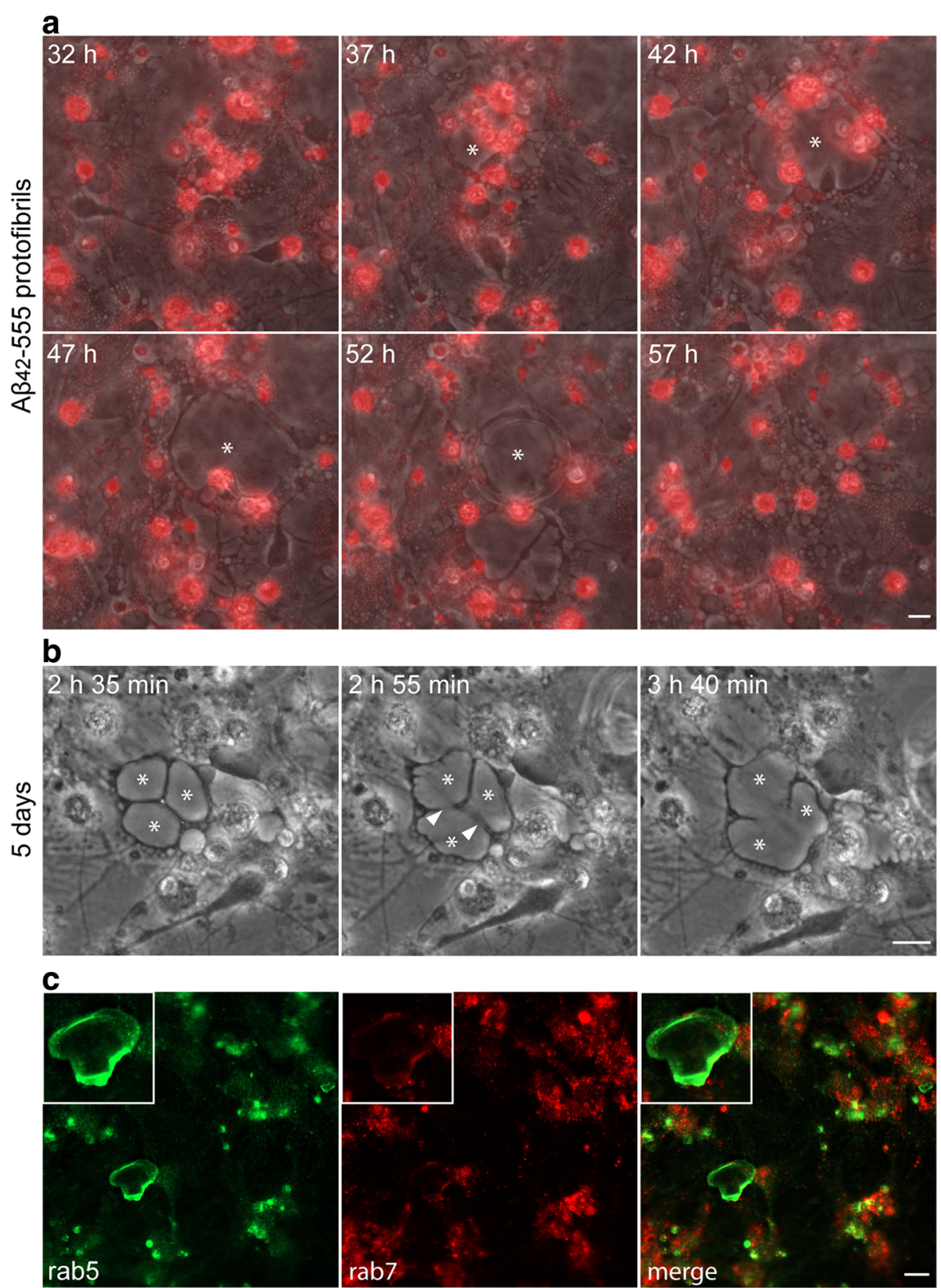

Fig. $6 \mathrm{~A} \beta_{42}$ protofibril treatment results in formation of enlarged endosomes. Time-lapse experiments demonstrate that $A \beta_{42}$ protofibril treatment induces the formation of enlarged, dynamic vacuoles $\left(^{*}\right)$ in the astrocytes (a). The enlarged vacuoles fuse (white arrow heads) with adjacent vacuoles; forming giant vacuoles with a diameter of 30-50 $\mu \mathrm{m}$ (b). Immunocytochemistry show that the vacuoles express the early endosome marker Rab5 and to a lesser extent the late endosome marker Rab7 (c). Inset in left corner of image c shows higher magnification of relevant structure. Scale bars: $\mathbf{a}-\mathbf{b}=10 \mu \mathrm{m}, \mathbf{c}=20 \mu \mathrm{m}$

there was a significant increase in apoptotic neurons in cultures treated with microvesicles from $\mathrm{A} \beta_{42}$ protofibril exposed co-cultures compared to controls (Fig. 8f), demonstrating that $A \beta_{42}$ protofibril accumulation induces secretion of microvesicles with toxic content. Parallel neuronal cultures, exposed to intact $A \beta_{42}$ protofibrils, directly added to the medium, showed no difference in the percentage of TUNEL positive cell nuclei or the total number of cell nuclei, compared to untreated cultures (Additional file 12). Since the amount of microvesicles was unchanged (based on the Flotillin-1 expression), the apoptotic effect on neurons was due to the content of the microvesicles. $A \beta_{1-x}$ and $A \beta_{x-42}$ ELISA analysis of microvesicles isolated from the cell culture medium demonstrate that the microvesicles contained primarily an $\mathrm{N}$-terminally truncated form of $\mathrm{A} \beta_{42}$ (Fig. 8g). 

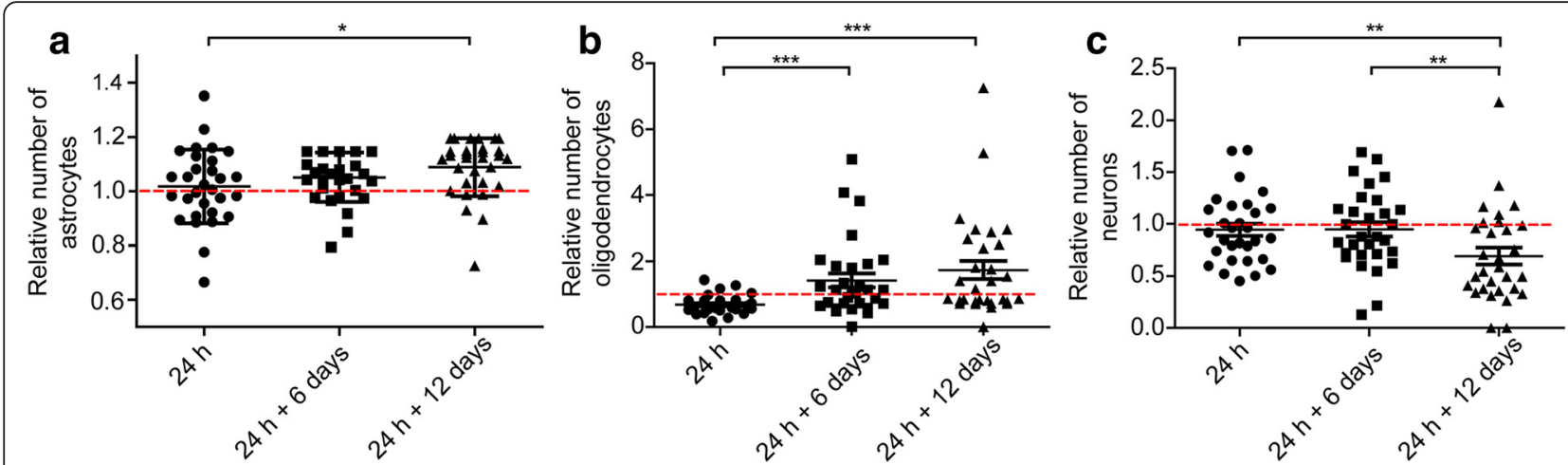

Fig. $7 \mathrm{~A} \beta_{42}$ protofibril treatment induces secondary neuronal cell death. The number of astrocytes in $A \beta_{42}$ protofibril exposed cultures is significantly increased from $24 \mathrm{~h}(1.0 \pm 0.1)$ to $24 \mathrm{~h}+12$ days $(1.1 \pm 0.1, P=0.011)$ (a). Similar to astrocytes, the number of oligodendrocytes increases from $24 \mathrm{~h}$ $(0.7 \pm 0.3)$ to $24 \mathrm{~h}+12$ days $(1.7 \pm 1.5, P<0.001)$ in $A \beta_{42}$ protofibril treated cultures $(\mathbf{b})$. $A \beta_{42}$ protofibril treatment has no direct effect on neurons, but the neuronal cell number significantly decreases (from both $24 \mathrm{~h}, 0.9 \pm 0.4, P=0.0061$ and $24 \mathrm{~h}+6$ days, $1.0 \pm 0.4, P=0.0083$ ) in the treated cultures 12 days $(0.7 \pm 0.5)$ after $A \beta$ removal $(\mathbf{c})$. The relative number of viable cells in $A \beta_{42}$ protofibril exposed cultures is normalized to viable cells in unexposed cultures. The experiments were performed in triplicates with independent cell cultures and 10 images/experiment were analyzed. Mann-Whitney U-test ${ }^{* * *} P<0.001$

\section{Discussion}

Many studies indicate that the widespread neuronal dysfunction in the AD brain is caused by soluble $A \beta$ aggregates, such as protofibrils, rather than the insoluble fibrils [8-13]. The mechanisms by which $A \beta_{42}$ protofibrils induce neuronal toxicity is however unclear. It has been suggested that $A \beta$ oligomers promote neuronal cell death, inhibit long-term potentiation and impair synaptic function and plasticity $[8,9,11,12,43-46]$. In the present study we show, by using a co-culture system of neurons and glia, that $A \beta_{42}$ protofibrils are not directly, but indirectly neurotoxic. Extensive engulfment of $A \beta_{42}$ protofibrils by the astrocytes in the co-culture results in long-term intracellular deposits of $A \beta$, severe lysosomal dysfunction and formation of N-terminally truncated $A \beta$ that is spread in the co-culture by microvesicle secretion.

Accumulation of $A \beta$ in the $A D$ brain is due to an imbalance between the $A \beta$ production and $A \beta$ clearance. Several studies indicate that monomeric $A \beta_{40}$ and $A \beta_{42}$ are degraded by cultured astrocytes following ingestion [47-49]. This conclusion was based on observations that the engulfed $A \beta$ was directly transported to LAMPpositive lysosomes following ingestion $[47,49,50]$. However, neither of the studies confirmed if $\mathrm{A} \beta$ degradation actually took place in the lysosomes. We hypothesized that aggregated species of $A \beta$, such as protofibrils, may be more difficult for the cells to handle than the monomeric form of the protein. Our results show that the degradation of $A \beta_{42}$ protofibrils in astrocytes is indeed extremely slow, although the ingested $A \beta$ is situated in LAMP-1 phagosomes/lysosomes. Instead, the $A \beta_{42}$ protofibrils accumulate in the astrocytes, leading to large, intracellular inclusions. In contrast to $A \beta_{42}$ protofibrils, $\mathrm{A} \beta_{40}$ monomers were not accumulated in the astrocytes, indicating that they are not overall slow degraders. We have previously compared phagocytosis of dead cells by astrocytes and macrophages (which are indistinguishable from activated microglia in the pathological brain) and found that astrocytes in contrast to the professional phagocytes store, rather than degrade ingested dead cells $[26,30]$. By using the pHrodo-labeling technique we demonstrated that material ingested by macrophages fuses with mature/acidic lysosomes within $5 \mathrm{~h}$, whereas material engulfed by astrocytes still had not fused with acidic lysosomes after 3 days. Thus, astrocytes are ineffective when it comes to degrading large/toxic material such as cell corpses and protein aggregates. Some reports indicate that astrocytes may be more efficient than microglia in taking up $A \beta$, particularly during the early stages of $\mathrm{AD}$ and astrocytes has been shown to gradually accumulate $\mathrm{A} \beta$ throughout cortex in $\mathrm{AD}$ patients [28, 29, 51-53]. However, the difference in degradation capacity of the two cell types has not been taken in account in these studies.

Our data show that glial cells, but not neurons accumulate $A \beta_{42}$ protofibrils. Since the glial cells in our differentiated co-culture system do not die following $A \beta$ exposure, it is unlikely that the noted co-localization of $A \beta$ and dead nuclei is due to phagocytosis of dead $A \beta$ containing cells. Dead cells are however constantly ingested by the astrocytes during the differentiation process, when apoptosis is naturally occurring. These dead cells are then stored in the astrocytes for weeks. Hence, the co-localization is probably due to transportation of the ingested material to the same "garbage dumps" within the astrocytes. Moreover, the ingestion of $A \beta$ is very rapid. Our time-lapse experiments demonstrated that intracellular A $\beta-555$ deposits are visible already after $30 \mathrm{~min}$ (Fig. 2a). Over time the 555-signal of these deposits 


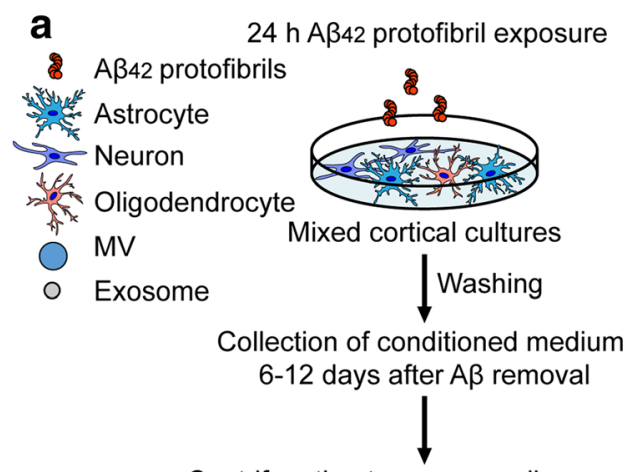

Centrifugation to remove cell remnants and apoptotic bodies,

$300 \times g$ for $5 \mathrm{~min}+2000 \times g$ for $10 \mathrm{~min}$

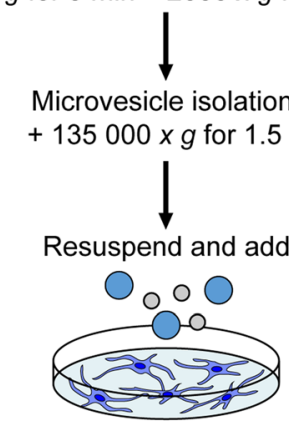

Neuronal cultures

Fixation and TUNEL assay

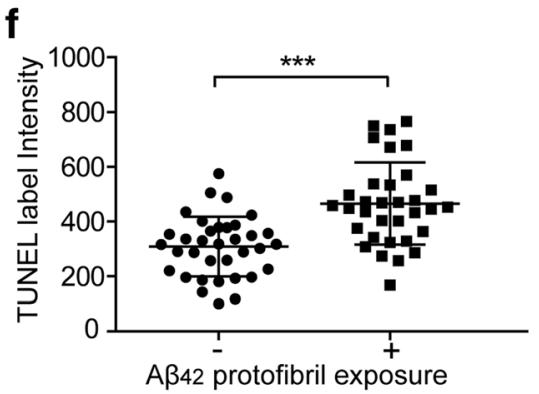

b

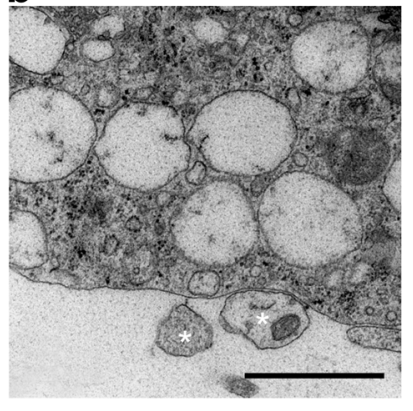

C

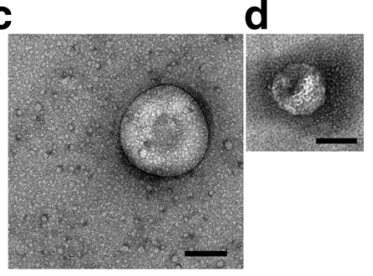

e

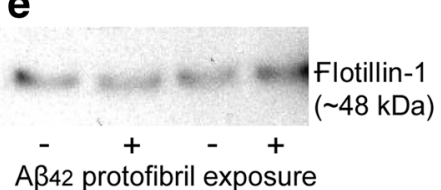

A $\beta 42$ protofibril exposure

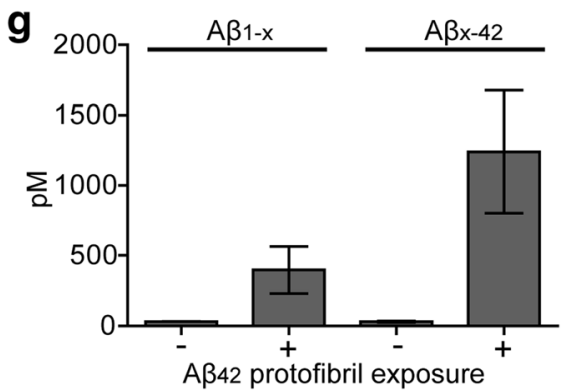

Fig. 8 Neuronal cell death is induced by secreted microvesicles. Illustration of the experimental setup (a). Electron microscopy images of $A \beta_{42}$ protofibril exposed co-cultures demonstrate microvesicle $\left(^{*}\right)$ secretion from a single astrocyte (b) and a larger (c) and smaller (d) microvesicle present in the cell culture medium. Western blot analysis show that the isolated microvesicles express Flotillin-1, but that the levels are unchanged in $A \beta_{42}$ protofibril treated cultures, compared to controls (e). TUNEL assays demonstrate a significant increase $(P<0.001)$ in apoptotic neurons following treatment with microvesicles from $A \beta_{42}$ protofibril exposed co-cultures (465.4 \pm 150.4 ), compared to microvesicles from untreated co-cultures (308.3 \pm 109.2$)$ (f). The experiments were performed in triplicates with independent cell cultures and 10 images/experiment were analyzed. Microvesicles isolated from medium collected 6 and 12 days after $A \beta_{42}$ protofibril exposure contain $A \beta$ as revealed in $A \beta_{1-x}(396.9 \pm 167.2 p M)$ and $A \beta_{x-42}(1239.0 \pm 438.7 p M)$ ELISA. The $A \beta_{1-x}$ concentration is lower than $A \beta_{x-42}$, indicating that there is a truncation of the $A \beta_{42} \mathrm{~N}$-terminus (g). Duplicate samples from 3 independent experiments were analyzed. Mann-Whitney $U$-test ${ }^{* * *} P<0.001$. Scale bars: $\mathbf{b}=1 \mu \mathrm{m}, \mathbf{c}-\mathbf{d}=100 \mathrm{~nm}$

becomes more and more intense, indicating that the $A \beta$ aggregates are constantly engulfed by the astrocytes and then transported to specific sites within the astrocytes.

In an attempt to identify reasons for the slow digestion of engulfed dead cells in primary astrocytes, we previously found that actin rings surround the phagosomes for long periods of time, which physically inhibit the phago-lysosome fusion [30]. Furthermore, astrocytes express high levels of Rab27a, a protein known to reduce the acidity of lysosomes by Nox 2 recruitment, in order to preserve antigens for presentation. We demonstrated that Nox2 co-localizes with the ingested material, indicating that it may influence antigen processing also in astrocytes, as they express MHC class II [30]. By 
inducing long-time acidification of astrocytic lysosomes using acidic nanoparticles, we could increase the digestion of astrocyte-ingested dead cells. The degradation was, however, normalized over time, indicating that inhibitory pathways are up-regulated in response to the enhanced acidification [30]. By staining the cell cultures with LysoTracker dye in the present study, we also found the lysosomes to be of low acidity, which probably contributes to the incomplete digestion of $A \beta$. Moreover, the deposition of aggregated $A \beta_{42}$ in astrocytes results in severe lysosomal dysfunction, including formation of enormous endosomes, indicating that the accumulation of $A \beta$ disturbs the endosome/lysosome machinery. Such enlarged endosomes were never observed in astrocytes storing cell corpses, or cultures exposed to $A \beta_{40}$ monomers, but only in $A \beta_{42}$ protofibril accumulating astrocytes. It is likely that this toxic effect of $A \beta_{42}$ protofibrils affects the astrocytes so that their slow degradation is further reduced.

The fact that the $A \beta_{42}$ deposits in astrocytes colocalize with the lysosomal marker LAMP-1 indicates that the lysosome function is crucial for $A \beta$ degradation. It is however not excluded that other degradation mechanisms, such as the proteasome machinery could be affected by the presence of toxic $A \beta$ aggregates in the cell. Sections of tg-ArcSwe mice revealed that the $A \beta$ plaques were surrounded by LAMP-2 immunoreactive astrocytes. These findings agree with previous reports of increased LAMP-1 in cerebral cortex of AD patients as the disease progresses [54] and in brains of APPSL-Tg mice during aging [55]. Interestingly, it has been demonstrated that activation of transcription factor EB (TFEB), a regulator of lysosome biogenesis, enhanced uptake and degradation of $A \beta$ in astrocytes, attenuating plaque pathology in APP/PS1 transgenic mice [49]. By studying the lysosomal storage disorder, multiple sulfatase deficiency (MSD), it has been suggested that normal autophagic, endocytic, and lysosomal vesicle trafficking is essential for preventing neurodegeneration [56]. One of the earliest pathological signs observed in patients with $\mathrm{AD}$ is the accumulation of numerous enlarged autophagic and endosomal vesicles, due to defective autophagylysosomal degradation in neurons [33, 57, 58]. The defect may result from impaired vesicle fusion among autophagosomes, endosomes and lysosomes [34, 57, 59, 60] or failure of lysosomal acidification [61]. $A \beta_{42}$ has been shown to induce autophagy and lysosomal degradation dysfunctions which may lead to indigestible $A \beta$ storage inside the vesicles $[62,63]$.

The accumulated $A \beta$ in the astrocytes was partly modified to $\mathrm{N}$-terminally truncated $\mathrm{A} \beta$. The absence of the full $A \beta N$-terminus may thereby, to some extent, underestimate the intracellular $A \beta$ concentration when analyzing cell lysate with the $\mathrm{N}$-terminus dependent
$A \beta_{1-x}$ and $A \beta$ protofibril ELISA. N-terminally truncated $A \beta$, often bearing amino-terminal Glu3 which eventually modifies to pyroglutamate $(A \beta N 3 p E-x)$, is found both in extracellular, intracellular and vascular deposits in $\mathrm{AD}$ and Down's syndrome brain tissue [64]. Astrocytes have been implied to take up $\mathrm{N}$-terminally truncated $A \beta$ from fleecy amyloid in AD brains and diffuse plaques from non-demented individuals $[65,66]$. As we exposed astrocytes with full length $A \beta_{42}$ in the protofibrillar form, we propose that the truncation of $A \beta$ in fact might occur by the endosomal/lysosomal pathway in the astrocytes. Since the N-terminals are sticking out from the $A \beta$ protofibrils, they are easily accessible, compared to the $\mathrm{C}$-terminals that are hidden in the core of the aggregate. We suggest that since the astrocytes degradation system is ineffective, degradation is not completed and partly degraded (N-terminally truncated) $\mathrm{A} \beta$ is left. $\mathrm{N}$-terminally truncated $A \beta$ has been found to be more resistant to degradation, more prone to aggregate and more toxic than full - length $A \beta$ [67]. Our hypothesis is that astrocytes try to be "helpful", but are overwhelmed by the difficulties they face. Hence, they cannot fulfill their task to degrade the $A \beta$ protofibrils, and instead of being "helpful" they promote spreading of the $A \beta$ pathology, by secreting $A \beta$ aggregates that had been only partly degraded. In the $\mathrm{AD}$ brain, reactive astrocytes are attracted to the $A \beta$ plaques and are highly exposed to various forms of $A \beta$ aggregates. Engulfment of $A \beta$ by astrocytes may initially be a protective clearance mechanism, but based on our data, overburden of the astrocytes is clearly detrimental.

Astrocytes are highly responsible for maintaining brain homeostasis and although our results show that the high A $\beta$ load does not induce apoptosis in astrocytes, their normal functions are probably severely affected. Misconduct in the performance of astrocytes normal responsibilities would affect processes such as metabolic support of neurons, modification of synapse signaling, recycling of neurotransmittors, regulation of blood flow and function of the blood brain barrier [2, 3].

The way in which $A \beta$ pathology spreads in the $A D$ brain has been debated for many years. Experimental evidence suggests that amyloid proteins, such as $A \beta$, indeed can seed and transmit pathology in the brain. For example, it has been shown that injection of cortical extracts from post-mortem $\mathrm{AD}$ brains into the brains of transgenic APP mice, aggravates plaque pathology within five months [68] and longer incubation also induces tau pathology [69]. The cellular mechanism behind the spreading of AD pathology is still unclear, but both cellto-cell transmission [70] and secretion into the extracellular space [71] have been suggested as possible pathways. Ineffective degradation of $A \beta$ may lead to spreading of $A D$ pathology, due to secretion of $A \beta$ containing microvesicles $[35,72]$. Interestingly, $A \beta$ peptides have been found to be 
released from $\mathrm{A} \beta \mathrm{PP}$ transfected neuroblastoma cells via exosomes. Moreover, the exosome specific proteins Alix and Flotillin-1, have been found around plaques in human $\mathrm{AD}$ brains and within senile plaques of $\operatorname{Tg} 2756$ mice, respectively $[72,73]$. We have previously shown that astrocytes express high levels of proteins known to promote vesicle secretion $[26,30,74,75]$. In contrast to neurons, which mainly secrete $A \beta$ beginning at Asp1, the majority of $A \beta$ secreted from glial cells has proven to be N-terminally truncated [76].

\section{Conclusion}

In conclusion, we demonstrate that astrocytes engulf large amounts of protofibrillar $A \beta_{42}$ that are only partly digested and stored in the cells for very long times. The intracellular A $\beta$ accumulation results in severe astrocytic endosome/ lysosome defects and microvesicle-induced neurotoxicity. In familial AD, with mutations in the A $\beta \mathrm{PP}$, Presenilin 1 or Presenilin 2 genes, increased $A \beta$ production or increased $A \beta_{42} / A \beta_{40}$ ratio lead to $A D$. However, in sporadic $A D$ it is likely that defective $A \beta$ clearance is the culprit. Thus, accumulation of $A \beta$ in astrocytes could play a vital role in the sporadic form of the disease and a better understanding of astrocytes role in $\mathrm{AD}$ initiation and progression is highly desirable.

\section{Methods}

\section{Synthetic $A \beta_{42}$ protofibrils}

Fluorescent HiLyte ${ }^{\mathrm{Tm}}$ Fluor 555-labeled $\mathrm{A} \beta_{42}\left(\mathrm{~A} \beta_{42}-555\right)$ peptides (Anaspec Inc) were diluted in $10 x$ phosphate buffered saline (PBS) to a concentration of $36 \mu \mathrm{M}$ followed by incubation for $4 \mathrm{~h}$ at $37{ }^{\circ} \mathrm{C}$. Synthetic $A \beta_{42}$ peptides (American Peptide Company Inc.) were prepared as previously described [13, 77-79]. A $\beta_{42}$ dissolved in $10 \mathrm{mM} \mathrm{NaOH}$ was mixed with $10 x \mathrm{PBS}$ to $443 \mu \mathrm{M}$ $(2 \mathrm{mg} / \mathrm{ml})$ and incubated $30 \mathrm{~min}$ at $37{ }^{\circ} \mathrm{C}$. Both $\mathrm{A} \beta_{42}-555$ protofibrils and unlabeled $A \beta_{42}$ protofibrils were centrifuged for $5 \mathrm{~min}$ at $17900 \times \mathrm{g}$ to remove any insoluble aggregates. Using the protofibril specific ELISA, mAb158 [41], we concluded that we had the best yield of $A \beta_{42}-555$ protofibrils after $4 \mathrm{~h}$ incubation in $37^{\circ} \mathrm{C}$. $\mathrm{A} \beta_{42}-555$ protofibrils were readily detected by mAb158 ELISA and there was no significant difference between 555-labeled and unlabeled $A \beta_{42}$ protofibrils (Additional file 13). To estimate the purity $(>95 \%)$ and size of the $A \beta_{42}$ protofibrils, $50 \mu \mathrm{l}$ of $250 \mu \mathrm{g} / \mathrm{ml} \mathrm{A} \beta_{42}$ protofibrils were analyzed by sizeexclusion chromatography (SEC) using a Superdex 75 column. The $A \beta_{42}$ protofibrils ( $>95 \%$ purity) eluted in the void volume and was estimated to be $>75 \mathrm{kDa}$ based on the cutoff size of the Superdex column (Fig. 9).

\section{Animals}

All experiments involving animals were performed at Uppsala University, Sweden. The experiments were approved by the Uppsala County Animal Ethics Board (ethical permit number: C75/13, valid 2013-06-28 to 2018-06-28), following the rules and regulations of the Swedish Animal Welfare Agency, in compliance with the European Communities Council Directive of 22 September 2010 (2010/63/EU). C57/BL6 mice were used for cell culture studies and tg-ArcSwe mice, harboring the human Arctic (E693G) and Swedish (KM670/671NL) ABPP mutations (Lord 2007) for in vivo experiments. The animals were housed at the National Veterinary Institute, Uppsala or the animal facility at Uppsala University Hospital, Uppsala in a 12-12 dark-light cycle. The mice were kept in an enriched environment and given water and food $a d$ libitum.

\section{Neural cell cultures}

Cerebral cortices from C57/BL6 mice of embryonal day 14 (E14) were dissected in Hank's buffered salt solution supplemented with $50 \mathrm{U} / \mathrm{ml}$ Penicillin, $50 \mathrm{mg} / \mathrm{ml}$ Streptomycin and $8 \mathrm{mM}$ Hepes buffer (HBSS, all from Invitrogen). The cortices were dissociated in fresh HBSS, centrifuged at $150 \times \mathrm{g}$ and resuspended in cell culture medium.

\section{Co-cultures of neurons and glia}

According to Loov et al. [30], the cells were expanded in DMEM/F12-GlutaMAX supplemented with $1 x$ B27, 50 $\mathrm{U} / \mathrm{ml}$ Penicillin, $50 \mathrm{mg} / \mathrm{ml}$ Streptomycin and $8 \mathrm{mM}$ Hepes buffer, $10 \mathrm{ng} / \mathrm{ml}$ bFGF (all from Invitrogen) and $20 \mathrm{mg} / \mathrm{ml}$ EGF (VWR). Neurospheres were passaged every second or third day by dissociation in HBSS and resuspended in medium with bFGF and EGF. Prior to experiments, the cells were plated as a monolayer, at a concentration of $1.5 \times 10^{5}$ cells $/ \mathrm{ml}$, on cover slips (In Vitro Diagnostics) or cell culture dishes (Falcon), coated with Poly-L-Ornithine (Sigma-Aldrich) and Laminin (Invitrogen). After $24 \mathrm{~h}$, the medium was replaced with mitogen-free medium to initiate neural stem cell differentiation to a mixed population of neurons, astrocytes and oligodendrocytes, but not microglia. This is a well characterized cell culture system, based on the lineage restricted differentiation of embryonic, cortical stem cells [38, 80, 81]. To drive the differentiation towards generation of exclusively astrocytes, $10 \mathrm{ng} / \mathrm{ml}$ cilliary neurotrophic factor (CNTF) was added to the mitogen-free medium throughout the differentiation process $[37,38]$. During the seven days differentiation period, the cell culture medium was changed every second or third day. Only neurospheres from passage 2-4 were used for experiments.

\section{Neuronal cultures}

Following dissection and dissociation the cells were seeded on Poly-L-Ornithine and Laminin coated cover slips at a concentration of $8 \times 10^{4}$ cells $/ \mathrm{ml}$. The neurons 


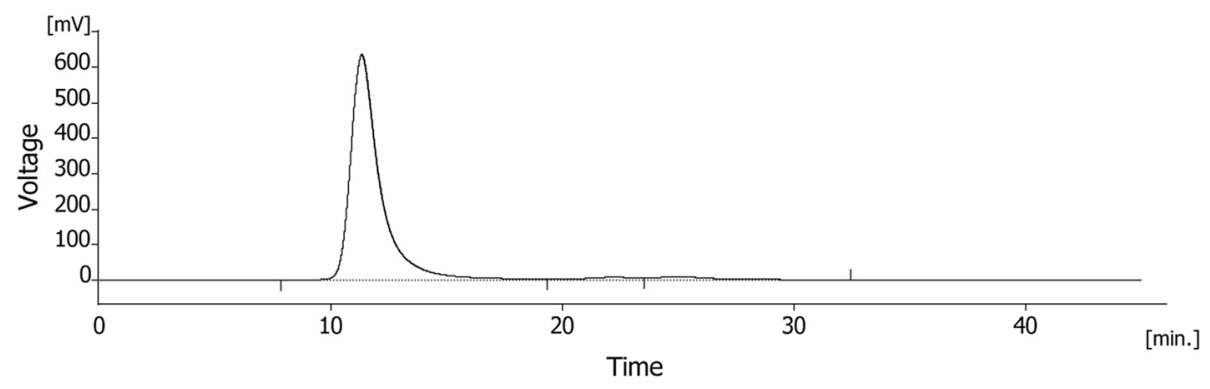

Fig. $9 \mathrm{~A} \beta_{42}$ protofibril characterization. A chromatogram following $A \beta_{42}$ protofibril analysis by SEC using a Superdex 75 column. The chromatograms show $\mathrm{mV}$ for the absorbance at $214 \mathrm{~nm}$ on the $y$-axis and the retention time in minutes on the $x$-axis

were cultured in neurobasal medium supplemented with $1 x$ B27, $50 \mathrm{U} / \mathrm{ml}$ Penicillin, $50 \mathrm{mg} / \mathrm{ml}$ Streptomycin and $20 \mathrm{mM}$ L-glutamine (Invitrogen) for 12 days (12 DIV) prior to experiment. The first day after seeding, the cell culture medium was fully replaced followed by changing half of the medium every second or third day.

\section{$A \beta$ stimulation}

Cell cultures differentiated into neurons and glia or astrocytes and pure neuronal cultures were treated with $0.1 \mu \mathrm{M} \quad \mathrm{A} \beta_{42}$ protofibrils (either 555-labeled or unlabeled) for $24 \mathrm{~h}$. Controls received fresh cell culture medium without $A \beta_{42}$ protofibrils. After $A \beta$ treatment, the cells were washed in cell culture media $x 3$ and the cover slips were transferred to new culture dishes. The cells were fixed, lysed $(24 \mathrm{~h})$ or cultured for additional 6 ( $24 \mathrm{~h}+6$ days) or 12 days $(24 \mathrm{~h}+12$ days) in $A \beta$ free cell culture medium prior to fixation or cell lysis.

\section{Microvesicles}

Co-cultures of neurons and glia were treated with $0.1 \mu \mathrm{M} \mathrm{A} \beta_{42}$ protofibrils for $24 \mathrm{~h}$ or left untreated. The cultures were thoroughly washed $x 3$ and were continuously cultured in medium only. From day 6 to day 12 following $A \beta_{42}$ protofibril treatment, the medium was harvested and centrifuged for $5 \mathrm{~min}$ at $300 x \mathrm{~g}$ to remove any cell remnants. For microvesicle preparations (containing exosomes and larger vesicles), the supernatants were centrifuged for $10 \mathrm{~min}$ at $2000 \times \mathrm{g}$ to remove apoptotic bodies followed by ultracentrifugation for $1.5 \mathrm{~h}$ at $4{ }^{\circ} \mathrm{C}$ at $135000 \times \mathrm{g}$. The ultracentrifugation was performed in Ultra-Clear centrifuge tubes (Beckman Coulter) using a Beckman LE-80 ultracentrifuge. For the neurotoxicity assays, the pellets containing microvesicles were reconstituted in neurobasal medium supplemented with $1 x$ B27, Penicillin and Streptomycin and L-glutamine (Invitrogen) and added to cortical neurons. After $48 \mathrm{~h}$, the neuronal cultures were fixed and the number of apoptotic cells quantified. Parallel control cultures were exposed to $0.1 \mu \mathrm{M} \mathrm{A} \beta_{42}$ protofibrils or left untreated for $48 \mathrm{~h}$ prior to fixation. For analysis of the $A \beta$ content, the isolated microvesicles were lysed in ice cold lysis buffer $(20 \mathrm{mM}$ Tris pH 7.5, $0.5 \%$ Triton X-100, $0.5 \%$ deoxycholic acid, $150 \mathrm{mM} \mathrm{NaCl}, 10 \mathrm{mM}$ EDTA, $30 \mathrm{mM} \mathrm{NaPyroP}$ and protease inhibitor (Roche)) and stored in $-70{ }^{\circ} \mathrm{C}$ until time of analysis by ELISA.

\section{Immunostaining of cell cultures}

Cover slips were fixed for 15 min in RT with $4 \%$ paraformaldehyde and permeabilized and blocked with $0.1 \%$ Triton X-100 (both from Sigma-Aldrich) and $5 \%$ normal goat serum (NGS, Bionordica) in PBS for $30 \mathrm{~min}$ in RT. Primary antibodies were incubated in $0.1 \%$ Triton X-100 with $0.5 \%$ NGS for $1-4 \mathrm{~h}$ in RT or $\mathrm{O} / \mathrm{N}$ in $4{ }^{\circ} \mathrm{C}$. Thereafter, cover slips were washed thoroughly in PBS $x 3$ between each step. Incubation with secondary antibodies was performed in $0.1 \%$ Triton X-100 and $0.5 \%$ NGS for $45 \mathrm{~min}$ in $37^{\circ} \mathrm{C}$ or $1 \mathrm{~h}$ in RT. The following primary antibodies were used in the study: rabbit anti-Glial Fibrillary Acidic Protein (GFAP, 1:400, DakoCytomation), mouse anti-GFAP (1:400, Sigma-Aldrich), mouse anti-2',3'-Cyclic-nucleotide 3'-phosphodiesterase (CNPase, 1:500, Sigma-Aldrich), mouse anti- $\beta$ III tubulin (1:200, Covance), rabbit antiLysosome-associated membrane protein-1 (LAMP-1, 1:200, Abcam), rabbit anti-Rab5 (1:1000, Abcam), mouse anti-Rab7 (1:1000, Abcam), polyclonal rabbit anti-A $\beta_{42}$ (1:200, Invitrogen), monoclonal mouse anti- $\mathrm{A} \beta$ antibody, 6E10 $(10 \mu \mathrm{g} / \mathrm{ml}$, epitope: $3-8$, Signet $)$, the monoclonal mouse anti-A $\beta$ antibody, mAb1C3 $(10 \mu \mathrm{g} / \mathrm{ml}$, epitope: 3 8) [41] and monoclonal mouse anti- $A \beta$ protofibril selective antibody, mAb158 $(10 \mu \mathrm{g} / \mathrm{ml})$ [41]. Secondary antibodies used were: AlexaFluor 488, 555 and 647, all against mouse or rabbit (1:200, Molecular probes). To study acidic lysosomes, $0.5 \mu \mathrm{M}$ LysoTracker red DND-99 (ThermoFisher) was added to the cell culture medium $2 \mathrm{~h}$ prior to fixation. Neuronal apoptosis was measured using terminal (TdT)-mediated dUTP-biotin reaction mixture (TUNEL, Roche Biochemicals) according to the manufacturer's instructions. The cover slips were mounted on microscope glass slides using vectashield hard set mounting medium with DAPI (DAKO). A Zeiss Observer Z1 Microscope and Carl Zeiss LSM700 confocal microscope 
(Zeiss) were used for analysis. Images and confocal z-stacks were visualized with Zen 2012 software.

\section{Time-lapse experiments}

Time-lapse experiments were performed at $37{ }^{\circ} \mathrm{C}$ in humidified $5 \% \mathrm{CO}_{2}$ in air, using a Nikon Biostation IM Live Cell Recorder (Nikon). The cells were cultured at a concentration of $1.5 \times 10^{5}$ cells $/ \mathrm{ml}$, in time-lapse culture dishes (VWR) and pictures were taken every $10^{\text {th }}$ minute for up to 5 days.

\section{Transmission electron microscopy \\ Cells}

Cells were briefly washed in PBS prior to fixation in $2.5 \%$ glutaraldehyde $\left(1 \mathrm{~h}\right.$ or $\mathrm{O} / \mathrm{N}$ in $\left.4{ }^{\circ} \mathrm{C}\right)$. The dishes containing the cells were rinsed in $0.15 \mathrm{M} \mathrm{Na}$-caccodylate and incubated for $1 \mathrm{~h}$ in $1 \%$ osmium tetroxide in Na-caccodylate at RT followed by Na-caccodylate rinse. Dehydration was performed with $70 \%$ ethanol for $30 \mathrm{~min}, 95 \%$ ethanol for $30 \mathrm{~min}$ and $99.7 \%$ ethanol for $1 \mathrm{~h}$. A thin layer of newly made plastic (Agar 100 resin kit, Agar Scientific Ltd) was added for $1 \mathrm{~h}$ to permit evaporation of the alcohol. The plastic was poured off and a second plastic layer was added and left $\mathrm{O} / \mathrm{N}$ in a desiccator. Next, plastic was heated up in an oven to enable its removal and a thicker, newly made plastic layer was added. The dishes were incubated in desiccator for $1-4 \mathrm{~h}$ before polymerization in oven $\left(60^{\circ} \mathrm{C}\right)$ for $48 \mathrm{~h}$. Cells were sectioned using Leica ultracut UTC ultrotome (Rowaco $\mathrm{AB}$ ) and studied in a Tecnai G2 transmission electron microscope (FEI Company). ORIUS SC200 CCD was used as camera and Gatan Digital Micrograph as software (both Gatan Inc.).

\section{Microvesicles}

Microvesicles were isolated by ultracentrifugation as described above and reconstituted in PBS. Samples were added onto a formvar-coated 200-mesh grid (Oxford Instruments) and incubated for $45 \mathrm{~min}$ in RT. The grid was dried and $1 \%$ uranyl acetate was added for $10 \mathrm{~s}$. Before analysis in a Tecnai G2 transmission electron microscope (FEI Company), the grid was dried for at least 15 min. ORIUS SC200 CCD was used as camera and Gatan Digital Micrograph as software (both Gatan Inc.).

\section{Cell lysates}

For $A \beta$ quantification studies, co-cultures of neurons and glia were seeded out in a concentration of $2.4 \times 10^{5}$ cells $/ \mathrm{ml}$ in $60 \mathrm{~mm} \times 15 \mathrm{~mm}$ cell culture dishes (Corning). Following removal of the cell culture medium, $100 \mu$ ice cold lysis buffer (20 mM Tris pH 7.5, $0.5 \%$ Triton X-100, $0.5 \%$ deoxycholic acid, $150 \mathrm{mM} \mathrm{NaCl}, 10 \mathrm{mM}$ EDTA, $30 \mathrm{mM}$ $\mathrm{NaPyroPand}$ protease inhibitor, Roche) was added to the dish. The lysed cells were collected using a cell lifter (Costar), transferred to Eppendorf tubes, incubated on ice for $30 \mathrm{~min}$ and centrifuged $\left(30 \mathrm{~min}, 4{ }^{\circ} \mathrm{C}, 12000 \times \mathrm{g}\right)$. The supernatant was collected and the remaining pellet was dissolved in $50 \%$ formic acid and sonicated in $4 \times 4 \mathrm{~s}$ pulses for 30 effective seconds at $50 \%$ amplitude. Both the supernatants and pellets were stored in $-70{ }^{\circ} \mathrm{C}$ until time of analysis by ELISA.

\section{$A \beta_{1-x}$ and $A \beta_{x-42}$ ELISAs}

For $A \beta_{1-x}$ ELISA [82] ninety-six well EIA/RIA plates (Corning Inc.) were coated $\mathrm{O} / \mathrm{N}$ at $4{ }^{\circ} \mathrm{C}$ with the $\mathrm{N}$ terminus (epitope 1-5) antibody mAb82E1 (100 ng/well, IBL-Hamburg) in PBS. Plates were blocked with $1 \%$ bovine serum albumin (BSA) in PBS for $2 \mathrm{~h}$ in RT. Standard series of synthetic $A \beta_{42}$ monomers (American Peptide) and samples (all except pellets of the lysates) were denatured by boiling for $5 \mathrm{~min}$ in $0.5 \%$ sodium dodecyl sulfate (SDS) to avoid impaired detection caused by aggregated $A \beta$ [83]. Before addition to plates, all SDS treated samples were diluted $x 10$ to decrease the SDS concentration and incubation followed for $2 \mathrm{~h}$. Biotinylated mAb4G8 (0.3 $\mu \mathrm{g} / \mathrm{ml}$, Covance), specific for the mid region of $A \beta$, was used as secondary antibody and incubated for $1 \mathrm{~h}$ followed by incubation with streptavidin coupled HRP (1:2000, Mabtech AB) for $1 \mathrm{~h}$. K-blue enhanced (Neogen Corporation) was used as HRP substrate and the reaction was stopped with $1 \mathrm{M} \mathrm{H}_{2} \mathrm{SO}_{4}$. Plates were measured by Tecan Infinite M200 PRO spectrophotometer (Tecan Group Ltd.) at $450 \mathrm{~nm}$ and analyzed with Magellan v7.0 software (Tecan Group Ltd.). Washing was performed by adding $250 \mu \mathrm{l}$ washing buffer (phosphate buffered $\mathrm{NaCl}$ with $0.1 \%$ Tween 20 and $0.15 \%$ Kathon) $x 3$ repetitions between each step of the ELISA. All dilutions occurred in ELISA incubation buffer $(0.05 \%$ Tween, $0.1 \%$ BSA and $0.15 \%$ Kathon in $\mathrm{PBS}$ at $\mathrm{pH}$ 7.4). For the $\mathrm{A} \beta_{\mathrm{x}-42}$ ELISA, polyclonal $\mathrm{A} \beta_{42}$ antibody (100 ng/well, Agrisera) and biotinylated mAb4G8 $(0.5 \mu \mathrm{g} / \mathrm{ml})$ was used as primary and secondary antibody, respectively. $A \beta_{x-42}$ ELISA [13] was performed according to the same protocol as the $A \beta_{1-\mathrm{x}}$ ELISA, except for prolonged incubation times for blocking, sample (both $\left.\mathrm{O} / \mathrm{N}, 4{ }^{\circ} \mathrm{C}\right)$ and secondary antibody $(2 \mathrm{~h}, \mathrm{RT})$ and increased SA-HRP dilution (1:5000). The pellet samples were neutralized with $1 \mathrm{M}$ Trizma base + $0.5 \mathrm{M} \mathrm{Na}_{2} \mathrm{HPO}_{4}$ prior to the ELISA analysis.

\section{$A \beta$ protofibril ELISA}

$A \beta$ protofibril ELISA using mAb158, was performed according to the protocol described by Englund et al. [41]. In short, ninety-six well EIA/RIA plates (Corning Inc.) were coated with $200 \mathrm{ng} /$ well of mAb158 in $100 \mu \mathrm{l}$ PBS at $4{ }^{\circ} \mathrm{C} \mathrm{O} / \mathrm{N}$. Plates were blocked with $1 \% \mathrm{BSA}$ in PBS with $0.15 \%$ Kathon. Standard series of synthetic $A \beta_{42}$ protofibrils and samples were added to the plates for $2 \mathrm{~h}$ incubation in RT. All dilutions occurred in ELISA 
incubation buffer. After washing the plate, $0.5 \mu \mathrm{g} / \mathrm{ml}$ of biotinylated mAb158 was added and incubated for $1 \mathrm{~h}$ in RT. Subsequent steps and washing steps were performed as previously described in the $A \beta_{1-x} E L I S A$ method.

\section{Immunostaining of mouse brain tissue}

Twelve-fourteen-month-old tg-ArcSwe mice were perfused with isotonic saline solution followed by $4 \%$ phosphate-buffered formaldehyde (Histolab AB). The brains were frozen and cryo-sectioned sagittally to a thickness of $14 \mu \mathrm{m}$ and then permeabilized and blocked in $0.3 \%$ Triton X-100 in PBS containing $5 \%$ NGS for $1 \mathrm{~h}$ in RT. The sections were incubated at $4{ }^{\circ} \mathrm{C} \mathrm{O} / \mathrm{N}$ with primary antibody diluted in $0.3 \%$ Triton/PBS with $0.5 \%$ NGS and thoroughly washed in $0.3 \%$ Triton/PBS. Thereafter, sections were incubated for $1 \mathrm{~h}$ in RT with secondary antibody diluted in $0.3 \%$ Triton/PBS with $0.5 \%$ NGS before repeating the washing step. The sections were mounted on microscope glass slides with Vectashield containing DAPI (Vector). Primary antibodies used were: rabbit anti-GFAP (1:400, DakoCytomation), mouse antiGFAP (1:500, Sigma), rat anti-LAMP-2 (1:400, Abcam) and mAb158 $(5 \mu \mathrm{g} / \mathrm{ml})$. Secondary antibodies used were AlexaFluor 488 against mouse, rabbit and rat or AlexaFluor 555 against mouse and rabbit (1:500, Molecular probes).

\section{Western blot analysis}

Microvesicle lysates were prepared as described above. $26 \mu \mathrm{l}$ of each sample was loaded to a $4-12 \%$ Bis-Tris Gel (NuPAGE, Life Technologies). Novex ${ }^{\circ}$ Sharp Standard (Life technologies) was used as a standard. The gel was run for $1 \mathrm{~h}$ at $175 \mathrm{~V}$ in MES buffer (NuPage, Life Technologies) followed by transfer for $1 \mathrm{~h}$ at $20 \mathrm{~V}$ onto a PVDF membrane (Invitrogen). The membrane was blocked with $5 \%$ BSA in TBS with $0.2 \%$ Tween (TBS-T) for $1 \mathrm{~h}$ (RT), followed by washes in TBS-T and incubation with Flotillin-1 (mouse monoclonal, 1:500, BD Biosciences) antibody in $0.5 \%$ BSA in TBS-T over night $\left(4{ }^{\circ} \mathrm{C}\right)$. After extensive washes in TBS-T the membrane was incubated with a peroxidase-conjugated goat anti-mouse IgG (1:20 000, Pierce) antibody in $0.5 \%$ BSA in TBS-T for $1 \mathrm{~h}$ (RT) and then finally washed again in TBS-T. The enhanced chemiluminescence (ECL) system (GE Healthcare) was used for development.

$A \beta$ inclusions, area, intensity measures and cell counting Thirty images (10 images/cover slip from three independent cultures) were captured with an $x 40$ objective on a Zeiss Observer Z1, using exactly the same settings. For the co-localization studies the images were manually analyzed. The cells were divided into four categories; cells with no detectable levels of $A \beta_{42}-555$ protofibrils (-), cells with only small amounts of $A \beta_{42}-555$ protofibrils $(+)$, cells containing medium amounts (a couple of small $A \beta_{42}-555$ protofibril inclusions or larger $A \beta_{42}$ protofibril inclusions with low intensity of the 555 -staining) $(++)$ and cells with one or more large $A \beta_{42}-555$ protofibril inclusions (+++). For $A \beta$ intensity and area measurements, the images were analyzed with the Zen 2012 software (Zeiss). All area and intensity measurements of $A \beta$ were set manually in the software and the number of viable cells was determined by manually counting cell nuclei in each field. Due to low cell numbers, the $x 20$ objective was used when counting the number of viable neurons and oligodendrocytes. All images were analyzed in a blinded fashion.

\section{Statistics}

All experiments were performed in triplicates with independent cell cultures derived from embryos of different pregnant mice. The results are presented in scatter plots or box plots with mean $+/-$ standard deviation. Since the data was found not to meet the assumption of normal distribution, using the Shapiro-Wilk's W-test, unpaired $t$-test and Kruskal-Wallis ANOVA, followed by Mann-Whitney $U$-test for pair-wise comparisons was used. Level of significance were set to ${ }^{*} P<0.05$, ${ }^{* *}<0.01$ and $* * * 00.001$.

\section{Additional files}

Additional file 1: $A \beta_{42}$ protofibril deposits are found in astrocytes, but not in neurons. Co-cultures stained for astrocytes (GFAP), neurons ( $\beta$ III-tubulin) and $A \beta_{42}-555$ protofibrils demonstrate that astrocytes, but not neurons, contain large deposits of $A \beta_{42}-555$. Scale bars: $20 \mu \mathrm{m}$. (TIF 2925 kb)

Additional file 2: $A \beta$ inclusions co-localize with condensed nuclei of dead cells. $A \beta_{42}-555$ protofibril exposed cultures labelled with TUNEL confirm that $A \beta_{42}-555$ co-localizes with nuclei of dead cells. Scale bar: $20 \mu \mathrm{m}$. (TIF $716 \mathrm{~kb}$ )

Additional file 3: Intracellular localization of large $A \beta_{42}-555$ inclusions in astrocytes. Intersections from a 3D z-stack of an astrocyte exposed to $A \beta_{42}-555$ protofibrils demonstrate that $A \beta_{42}-555$ deposits are located intracellularly (arrow heads). DAPI (blue), GFAP (green) and $A \beta_{42}-555$ (red). Scale bars: $10 \mu \mathrm{m}$. (TIF $2239 \mathrm{~kb}$ )

Additional file 4: Immunostainings with $A \beta_{42}$ specific antibodies confirm $A \beta_{42}$ protofibril inclusions in astrocytes. After $24 \mathrm{~h} A \beta$ protofibril exposure, co-cultures were fixed and stained with GFAP and four different $A \beta$ antibodies; mAb1C3 (a), 6E10 (b), mAb158 (c) and polyclonal $A \beta_{42}$ antibody (d). All antibodies detect extensive intracellular $A \beta$ accumulation in astrocytes. Scale bars: $20 \mu \mathrm{m}$. (TIF $3705 \mathrm{~kb}$ )

Additional file 5: Astrocytes differentiated in the presence of CNTF contain $A \beta$ deposits. Pure (CNTF-treated) astrocytic cultures exposed to $A \beta_{42}-555$ protofibrils demonstrate that astrocytes contain large intracellular deposits of $A \beta_{42}-555$. Scale bar: $20 \mu \mathrm{m}$. (TIF $1446 \mathrm{~kb}$ )

Additional file 6: Time-lapse movie from $30 \mathrm{~min}$ to $24 \mathrm{~h}$ following $A \beta_{42}-555$ protofibril administration shows that astrocytes, but not neurons accumulate $A \beta_{42}-555$ protofibrils over time. Images are captured in $10 \mathrm{~min}$ intervals. (MP4 $5271 \mathrm{~kb})$

Additional file 7: $A \beta$ deposits in GFAP-positive astrocytes in the AD mouse brain. Immunohistochemistry of tg-ArcSwe mouse brain sections confirms that $A \beta$ co-localizes with GFAP-positive astrocytes surrounding the plaques. A $\beta$ (red), GFAP (green). Scale bar: $20 \mu \mathrm{m}$. (TIF $1591 \mathrm{~kb}$ ) 
Additional file 8: No accumulation of $A \beta_{42}$ monomers in the co-cultures.

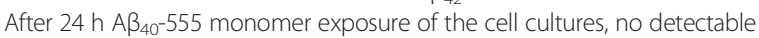
$A \beta_{40}-555$ is present in astrocytes (GFAP). Scale bar: $20 \mu \mathrm{m}$. (TIF $1768 \mathrm{~kb}$ )

Additional file 9: Time-lapse movie starting $24 \mathrm{~h}$ after $A \beta_{42}-555$ protofibril addition. $A \beta_{42}-555$ accumulation induced formation of enlarged, dynamic vacuoles in the astrocytes. The giant vacuoles eventually shrink or collapse, concurrently as new vacuoles appear in the same astrocyte. Images are captured in 10 min intervals. (MP4 $3765 \mathrm{~kb}$ )

Additional file 10: Time-lapse movie captured at day 5 after $A \beta_{42}$ protofibril addition. Enlarged vacuoles form and fuse in the astrocytes resulting in giant vacuoles with a diameter of $\sim 50 \mu \mathrm{m}$. Images are captured in 5 min intervals. (MP4 $2072 \mathrm{~kb}$ )

Additional file 11: $A \beta$ co-localizes with endosomal markers. Double stainings of $A \beta_{42}$ protofibril exposed cell cultures with antibodies to $A \beta /$ Rab5 or $A \beta /$ Rab7 demonstrate a clear co-localization of $A \beta$ inclusions and the early endosomal marker Rab5. Some co-localization is also noted for $A B$ and the late endosomal marker Rab7. Scale bars: 20 um. (TIF 1930 kb)

Additional file 12: $A \beta_{42}$ protofibrils do not directly induce neuronal cell death. Cortical neurons were exposed to $0.1 \mu \mathrm{M} \mathrm{A} \beta_{42}$ protofibrils for $48 \mathrm{~h}$ and TUNEL assay was performed to measure the number of apoptotic neurons. No significant differences are seen in the number of TUNEL positive cell nuclei or in the numbers of total cell nuclei compared to untreated neurons. (TIF $140 \mathrm{~kb}$ )

Additional file 13: $A \beta_{42}$ protofibril characterization. No considerable difference is noticed comparing serially diluted $A \beta_{42}$ protofibrils and $A \beta_{42}-555$ protofibrils with the $A \beta$ protofibril selective mAb158 ELISA. (TIF $149 \mathrm{~kb})$

\section{Abbreviations}

12 DIV: 12 days in vitro; AD: Alzheimer's disease; Aß: amyloid beta; BSA: bovine serum albumin; CNPase: 2',3'-Cyclic-nucleotide 3'-phosphodiesterase; CNTF: cilliary neurotrophic factor; CSF: cerebrospinal fluid; E14: embryonal day 14; ECL: enhanced chemiluminescence; GFAP: glial fibrillary acidic protein; HBSS: Hank's buffered salt solution; LAMP-1: lysosome-associated membrane protein-1; LAMP-2: lysosome-associated membrane protein-2; MSD: multiple sulfatase deficiency; NGS: normal goat serum; PBS: phosphate buffered saline; SDS: sodium dodecyl sulfate; SEC: size-exclusion chromatography; TFEB: transcription factor EB; TUNEL: terminal (TdT)-mediated dUTP-biotin reac tion mixture.

\section{Competing interests}

The authors declare that they have no competing interests.

\section{Authors' contributions}

SS designed and performed the experiments, interpreted the data and wrote the manuscript; EN performed experiments, participated in interpreting the data and revised the manuscript; RB performed immunohistochemistry, analyzed data and revised the manuscript; LS participated in the design of the study, performed SEC analysis and revised the manuscript; DS participated in the design of the study, interpreting the data and revised the manuscript: $\mathrm{LL}$ participated in the design of the study and revised the manuscript. AE designed and performed experiments, interpreted the data, coordinated the study and wrote the manuscript. All authors read and approved the final manuscript.

\section{Acknowledgements}

This study was supported by grants from the Swedish Research Council (\#2012-2172), the Alzheimer Foundation, Åhlén Foundation, Stohnes Foundation, Magnus Bergvalls Foundation and the Uppsala Berzelii Centre.

\section{Author details}

'Department of Public Health \& Caring Sciences/Molecular Geriatrics, Rudbeck Laboratory, Uppsala University, SE-751 85 Uppsala, Sweden. ${ }^{2}$ BioArctic Neuroscience AB, Warfvinges väg 35, SE-112 51 Stockholm, Sweden.

Received: 22 October 2015 Accepted: 15 April 2016 Published online: 12 May 2016

\section{References}

1. Avila-Munoz E, Arias C. When astrocytes become harmful: Functional and inflammatory responses that contribute to Alzheimer's disease. Ageing Res Rev. 2014;18C:29-40.

2. Sofroniew MV, Vinters HV. Astrocytes: biology and pathology. Acta Neuropathol. 2010;119:7-35.

3. Eroglu C, Barres BA. Regulation of synaptic connectivity by glia. Nature. 2010;468:223-31.

4. Pekny $M$, Wilhelmsson $U$, Pekna $M$. The dual role of astrocyte activation and reactive gliosis. Neurosci Lett. 2014;565:30-8.

5. Hardy JA, Higgins GA. Alzheimer's disease: the amyloid cascade hypothesis. Science. 1992;256:184-5.

6. Lue LF, Kuo YM, Roher AE, Brachova L, Shen Y, Sue L, Beach T, Kurth JH, Rydel RE, Rogers J. Soluble amyloid beta peptide concentration as a predictor of synaptic change in Alzheimer's disease. Am J Pathol. 1999;155:853-62.

7. McLean CA, Cherny RA, Fraser FW, Fuller SJ, Smith MJ, Beyreuther K, Bush Al, Masters CL. Soluble pool of Abeta amyloid as a determinant of severity of neurodegeneration in Alzheimer's disease. Ann Neurol. 1999:46:860-6.

8. Hartley DM, Walsh DM, Ye CP, Diehl T, Vasquez S, Vassilev PM, Teplow DB, Selkoe DJ. Protofibrillar intermediates of amyloid beta-protein induce acute electrophysiological changes and progressive neurotoxicity in cortical neurons. J Neurosci. 1999;19:8876-84.

9. Klyubin I, Walsh DM, Cullen WK, Fadeeva JV, Anwyl R, Selkoe DJ, Rowan MJ. Soluble Arctic amyloid beta protein inhibits hippocampal long-term potentiation in vivo. Eur J Neurosci. 2004;19:2839-46.

10. Klyubin I, Cullen WK, Hu NW, Rowan MJ. Alzheimer's disease Abeta assemblies mediating rapid disruption of synaptic plasticity and memory. Mol Brain. 2012;5:25.

11. Walsh DM, Klyubin I, Fadeeva JV, Cullen WK, Anwyl R, Wolfe MS, Rowan MJ, Selkoe DJ. Naturally secreted oligomers of amyloid beta protein potently inhibit hippocampal long-term potentiation in vivo. Nature. 2002;416:535-9.

12. Lacor PN, Buniel MC, Furlow PW, Clemente AS, Velasco PT, Wood M, Viola $\mathrm{KL}$, Klein WL. Abeta oligomer-induced aberrations in synapse composition, shape, and density provide a molecular basis for loss of connectivity in Alzheimer's disease. J Neurosci. 2007;27:796-807.

13. Sehlin D, Englund H, Simu B, Karlsson M, Ingelsson M, Nikolajeff F, Lannfelt L, Pettersson FE. Large aggregates are the major soluble Abeta species in AD brain fractionated with density gradient ultracentrifugation. PLoS One. 2012;7:e32014

14. Tucker S, Moller C, Tegerstedt K, Lord A, Laudon H, Sjodahl J, Soderberg L, Spens E, Sahlin C, Waara ER, et al. The murine version of BAN2401 (mAb158) selectively reduces amyloid-beta protofibrils in brain and cerebrospinal fluid of tg-ArcSwe mice. J Alzheimers Dis. 2015;43:575-88.

15. Savage MJ, Kalinina J, Wolfe A, Tugusheva K, Korn R, Cash-Mason T, Maxwell JW, Hatcher NG, Haugabook SJ, Wu G, et al. A sensitive abeta oligomer assay discriminates Alzheimer's and aged control cerebrospinal fluid. J Neurosci. 2014;34:2884-97.

16. Holtta M, Hansson $O$, Andreasson U, Hertze J, Minthon L, Nagga K, Andreasen N, Zetterberg $\mathrm{H}$, Blennow K. Evaluating amyloid-beta oligomers in cerebrospinal fluid as a biomarker for Alzheimer's disease. PLoS One. 2013;8:e66381

17. Herskovits AZ, Locascio JJ, Peskind ER, Li G, Hyman BT. A Luminex assay detects amyloid beta oligomers in Alzheimer's disease cerebrospinal fluid. PLoS One. 2013:8:e67898.

18. Fukumoto H, Tokuda T, Kasai T, Ishigami N, Hidaka H, Kondo M, Allsop D, Nakagawa M. High-molecular-weight beta-amyloid oligomers are elevated in cerebrospinal fluid of Alzheimer patients. FASEB J. 2010;24:2716-26.

19. Orre M, Kamphuis W, Osborn LM, Melief J, Kooijman L, Huitinga I, Klooster J, Bossers K, Hol EM. Acute isolation and transcriptome characterization of cortical astrocytes and microglia from young and aged mice. Neurobiol Aging. 2014;35:1-14.

20. Sastre M, Klockgether T, Heneka MT. Contribution of inflammatory processes to Alzheimer's disease: molecular mechanisms. Int J Dev Neurosci. 2006;24:167-76

21. Jones RS, Minogue AM, Connor TJ, Lynch MA. Amyloid-beta-induced astrocytic phagocytosis is mediated by CD36, CD47 and RAGE. J Neuroimmune Pharmacol. 2013:8:301-11.

22. Chung WS, Clarke LE, Wang GX, Stafford BK, Sher A, Chakraborty C, Joung J, Foo LC, Thompson A, Chen C, et al. Astrocytes mediate synapse elimination through MEGF10 and MERTK pathways. Nature. 2013;504:394-400. 
23. Chang GH, Barbaro NM, Pieper RO. Phosphatidylserine-dependent phagocytosis of apoptotic glioma cells by normal human microglia, astrocytes, and glioma cells. Neuro Oncol. 2000;2:174-83.

24. Magnus T, Chan A, Linker RA, Toyka KV, Gold R. Astrocytes are less efficient in the removal of apoptotic lymphocytes than microglia cells: implications for the role of glial cells in the inflamed central nervous system. J Neuropathol Exp Neurol. 2002;61:760-6.

25. Sokolowski JD, Nobles SL, Heffron DS, Park D, Ravichandran KS, Mandell JW. Brain-specific angiogenesis inhibitor-1 expression in astrocytes and neurons: implications for its dual function as an apoptotic engulfment receptor. Brain Behav Immun. 2011;25:915-21.

26. Loov C, Hillered L, Ebendal T, Erlandsson A. Engulfing astrocytes protect neurons from contact-induced apoptosis following injury. PLoS One. 2012;7:e33090.

27. Fellner $L$, Irschick $R$, Schanda K, Reindl M, Klimaschewski L, Poewe W, Wenning GK, Stefanova N. Toll-like receptor 4 is required for alpha-synuclein dependent activation of microglia and astroglia. Glia. 2013;61:349-60.

28. Nielsen HM, Mulder SD, Belien JA, Musters RJ, Eikelenboom P, Veerhuis R. Astrocytic A beta 1-42 uptake is determined by A beta-aggregation state and the presence of amyloid-associated proteins. Glia. 2010;58:1235-46.

29. Nagele RG, D'Andrea MR, Lee H, Venkataraman V, Wang HY. Astrocytes accumulate A beta 42 and give rise to astrocytic amyloid plaques in Alzheimer disease brains. Brain Res. 2003;971:197-209.

30. Loov C, Mitchell CH, Simonsson M, Erlandsson A. Slow degradation in phagocytic astrocytes can be enhanced by lysosomal acidification. Glia. 2015;63:1997-2009.

31. Liebl D, Griffiths G. Transient assembly of F-actin by phagosomes delays phagosome fusion with lysosomes in cargo-overloaded macrophages. J Cell Sci. 2009;122:2935-45.

32. Appelqvist $H$, Waster $P$, Kagedal $K$, Ollinger $K$. The lysosome: from waste bag to potential therapeutic target. J Mol Cell Biol. 2013:5:214-26.

33. Nixon RA, Yang DS, Lee JH. Neurodegenerative lysosomal disorders: a continuum from development to late age. Autophagy. 2008:4:590-9.

34. Nixon RA. Autophagy, amyloidogenesis and Alzheimer disease. J Cell Sci. 2007;120:4081-91.

35. Dinkins MB, Dasgupta S, Wang G, Zhu G, Bieberich E. Exosome reduction in vivo is associated with lower amyloid plaque load in the 5XFAD mouse model of Alzheimer's disease. Neurobiol Aging. 2014;35:1792-800.

36. Middeldorp J, Hol EM. GFAP in health and disease. Prog Neurobiol. 2011;93:421-43.

37. Bonni A, Sun Y, Nadal-Vicens M, Bhatt A, Frank DA, Rozovsky I, Stahl N, Yancopoulos GD, Greenberg ME. Regulation of gliogenesis in the central nervous system by the JAK-STAT signaling pathway. Science. 1997;278:477-83.

38. Johe KK, Hazel TG, Muller T, Dugich-Djordjevic MM, McKay RD. Single factors direct the differentiation of stem cells from the fetal and adult central nervous system. Genes Dev. 1996;10:3129-40.

39. Philipson $\mathrm{O}$, Hammarstrom $\mathrm{P}$, Nilsson KP, Portelius E, Olofsson T, Ingelsson M, Hyman BT, Blennow K, Lannfelt L, Kalimo H, Nilsson LN. A highly insoluble state of Abeta similar to that of Alzheimer's disease brain is found in Arctic APP transgenic mice. Neurobiol Aging. 2009;30:1393-405.

40. Lord A, Kalimo H, Eckman C, Zhang XQ, Lannfelt L, Nilsson LN. The Arctic Alzheimer mutation facilitates early intraneuronal Abeta aggregation and senile plaque formation in transgenic mice. Neurobiol Aging. 2006:27:67-77.

41. Englund H, Sehlin D, Johansson AS, Nilsson LN, Gellerfors P, Paulie S, Lannfelt L, Pettersson FE. Sensitive ELISA detection of amyloid-beta protofibrils in biological samples. J Neurochem. 2007;103:334-45.

42. Naslund J, Haroutunian V, Mohs R, Davis KL, Davies P, Greengard P, Buxbaum JD. Correlation between elevated levels of amyloid beta-peptide in the brain and cognitive decline. JAMA. 2000;283:1571-7.

43. Whalen BM, Selkoe DJ, Hartley DM. Small non-fibrillar assemblies of amyloid beta-protein bearing the Arctic mutation induce rapid neuritic degeneration. Neurobiol Dis. 2005;20:254-66.

44. Knobloch M, Farinelli M, Konietzko U, Nitsch RM, Mansuy IM. Abeta oligomer-mediated long-term potentiation impairment involves protein phosphatase 1-dependent mechanisms. J Neurosci. 2007;27:7648-53.

45. Shankar GM, Bloodgood BL, Townsend M, Walsh DM, Selkoe DJ, Sabatini BL. Natural oligomers of the Alzheimer amyloid-beta protein induce reversible synapse loss by modulating an NMDA-type glutamate receptor-dependent signaling pathway. J Neurosci. 2007;27:2866-75.

46. Li S, Jin M, Koeglsperger T, Shepardson NE, Shankar GM, Selkoe DJ. Soluble Abeta oligomers inhibit long-term potentiation through a mechanism involving excessive activation of extrasynaptic NR2B-containing NMDA receptors. J Neurosci. 2011;31:6627-38.

47. Basak JM, Verghese PB, Yoon H, Kim J, Holtzman DM. Low-density lipoprotein receptor represents an apolipoprotein E-independent pathway of Abeta uptake and degradation by astrocytes. J Biol Chem. 2012;287: 13959-71.

48. Koistinaho M, Lin S, Wu X, Esterman M, Koger D, Hanson J, Higgs R, Liu F, Malkani S, Bales KR, Paul SM. Apolipoprotein E promotes astrocyte colocalization and degradation of deposited amyloid-beta peptides. Nat Med. 2004;10:719-26.

49. Xiao Q, Yan P, Ma X, Liu H, Perez R, Zhu A, Gonzales E, Burchett JM, Schuler DR Cirrito JR, et al. Enhancing astrocytic lysosome biogenesis facilitates Abeta clearance and attenuates amyloid plaque pathogenesis. J Neurosci. 2014;34:9607-20

50. Kanekiyo T, Zhang J, Liu Q, Liu CC, Zhang L, Bu G. Heparan sulphate proteoglycan and the low-density lipoprotein receptor-related protein 1 constitute major pathways for neuronal amyloid-beta uptake. J Neurosci. 2011;31:1644-51.

51. Guenette SY. Astrocytes: a cellular player in Abeta clearance and degradation. Trends Mol Med. 2003;9:279-80.

52. Nicoll JA, Weller RO. A new role for astrocytes: beta-amyloid homeostasis and degradation. Trends Mol Med. 2003;9:281-2.

53. Shafer LE. Charging Ahead: An Introduction to Electromagnetism. In: Book Charging Ahead: An Introduction to Electromagnetism. City: National Science Teachers Association; 2001. p. 81.

54. Barrachina M, Maes T, Buesa C, Ferrer I. Lysosome-associated membrane protein 1 (LAMP-1) in Alzheimer's disease. Neuropathol Appl Neurobiol. 2006:32:505-16

55. Hashimoto T, Ogino K, Shin RW, Kitamoto T, Kikuchi T, Shimizu N. Agedependent increase in lysosome-associated membrane protein 1 and earlyonset behavioral deficits in APPSL transgenic mouse model of Alzheimer's disease. Neurosci Lett. 2010:469:273-7.

56. Di Malta C, Fryer JD, Settembre C, Ballabio A. Astrocyte dysfunction triggers neurodegeneration in a lysosomal storage disorder. Proc Natl Acad Sci U S A. 2012;109:E2334-2342.

57. Nixon RA, Wegiel J, Kumar A, Yu WH, Peterhoff C, Cataldo A, Cuervo AM Extensive involvement of autophagy in Alzheimer disease: an immunoelectron microscopy study. J Neuropathol Exp Neurol. 2005;64:113-22.

58. Shacka JJ, Roth KA, Zhang J. The autophagy-lysosomal degradation pathway: role in neurodegenerative disease and therapy. Front Biosci. 2008;13:718-36.

59. Boland B, Kumar A, Lee S, Platt FM, Wegiel J, Yu WH, Nixon RA. Autophagy induction and autophagosome clearance in neurons: relationship to autophagic pathology in Alzheimer's disease. J Neurosci. 2008;28:6926-37.

60. Yu WH, Cuervo AM, Kumar A, Peterhoff CM, Schmidt SD, Lee JH, Mohan PS, Mercken M, Farmery MR, Tjernberg LO, et al. Macroautophagy-a novel Beta-amyloid peptide-generating pathway activated in Alzheimer's disease. J Cell Biol. 2005;171:87-98.

61. Lee JH, Yu WH, Kumar A, Lee S, Mohan PS, Peterhoff CM, Wolfe DM Martinez-Vicente M, Massey AC, Sovak G, et al. Lysosomal proteolysis and autophagy require presenilin 1 and are disrupted by Alzheimer-related PS1 mutations. Cell. 2010;141:1146-58.

62. Ling D, Salvaterra PM. Brain aging and Abeta(1)(-)(4)(2) neurotoxicity converge via deterioration in autophagy-lysosomal system: a conditional Drosophila model linking Alzheimer's neurodegeneration with aging. Acta Neuropathol. 2011;121:183-91.

63. Ling D, Song HJ, Garza D, Neufeld TP, Salvaterra PM. Abeta42-induced neurodegeneration via an age-dependent autophagic-lysosomal injury in Drosophila. PLoS One. 2009;4:e4201.

64. Perez-Garmendia R, Hernandez-Zimbron LF, Morales MA, Luna-Munoz J, Mena R, Nava-Catorce M, Acero G, Vasilevko V, Viramontes-Pintos A, Cribbs DH, Gevorkian G. Identification of N-terminally truncated pyroglutamate amyloid-beta in cholesterol-enriched diet-fed rabbit and AD brain. J Alzheimers Dis. 2014;39:441-55.

65. Thal DR, Schultz C, Dehghani F, Yamaguchi H, Braak H, Braak E. Amyloid beta-protein (Abeta)-containing astrocytes are located preferentially near $\mathrm{N}$-terminal-truncated Abeta deposits in the human entorhinal cortex. Acta Neuropathol. 2000;100:608-17.

66. Yamaguchi H, Sugihara S, Ogawa A, Saido TC, Ihara Y. Diffuse plaques associated with astroglial amyloid beta protein, possibly showing a disappearing stage of senile plaques. Acta Neuropathol. 1998;95:217-22. 
67. De Kimpe L, van Haastert ES, Kaminari A, Zwart R, Rutjes H, Hoozemans JJ, Scheper W. Intracellular accumulation of aggregated pyroglutamate amyloid beta: convergence of aging and Abeta pathology at the lysosome. Age. 2013;35:673-87.

68. Kane MD, Lipinski WJ, Callahan MJ, Bian F, Durham RA, Schwarz RD, Roher AE, Walker LC. Evidence for seeding of beta -amyloid by intracerebral infusion of Alzheimer brain extracts in beta -amyloid precursor protein-transgenic mice. J Neurosci. 2000;20:3606-11.

69. Walker LC, Callahan MJ, Bian F, Durham RA, Roher AE, Lipinski WJ. Exogenous induction of cerebral beta-amyloidosis in betaAPP-transgenic mice. Peptides. 2002;23:1241-7.

70. Nath S, Agholme L, Kurudenkandy FR, Granseth B, Marcusson J, Hallbeck M. Spreading of neurodegenerative pathology via neuron-to-neuron transmission of beta-amyloid. J Neurosci. 2012;32:8767-77.

71. Zhao Y, Cui JG, Lukiw WJ. Natural secretory products of human neural and microvessel endothelial cells: Implications in pathogenic "spreading" and Alzheimer's disease. Mol Neurobiol. 2006;34:181-92.

72. Rajendran L, Honsho M, Zahn TR, Keller P, Geiger KD, Verkade P, Simons K. Alzheimer's disease beta-amyloid peptides are released in association with exosomes. Proc Natl Acad Sci U S A. 2006;103:11172-7.

73. Kokubo H, Saido TC, Iwata N, Helms JB, Shinohara R, Yamaguchi H. Part of membrane-bound Abeta exists in rafts within senile plaques in Tg2576 mouse brain. Neurobiol Aging. 2005;26:409-18.

74. Ostrowski M, Carmo NB, Krumeich S, Fanget I, Raposo G, Savina A, Moita CF, Schauer K, Hume AN, Freitas RP, et al. Rab27a and Rab27b control different steps of the exosome secretion pathway. Nat Cell Biol. 2010;12:19-30. sup pp 11-13.

75. Jancic C, Savina A, Wasmeier C, Tolmachova T, El-Benna J, Dang PM, Pascolo S, Gougerot-Pocidalo MA, Raposo G, Seabra MC, Amigorena S. Rab27a regulates phagosomal $\mathrm{pH}$ and $\mathrm{NADPH}$ oxidase recruitment to dendritic cell phagosomes. Nat Cell Biol. 2007;9:367-78.

76. Oberstein TJ, Spitzer P, Klafki HW, Linning P, Neff F, Knolker HJ, Lewczuk P, Wiltfang J, Kornhuber J, Maler JM. Astrocytes and microglia but not neurons preferentially generate $\mathrm{N}$-terminally truncated Abeta peptides. Neurobiol Dis. 2015;73:24-35

77. Sehlin D, Sollvander S, Paulie S, Brundin R, Ingelsson M, Lannfelt L, Pettersson FE, Englund $\mathrm{H}$. Interference from heterophilic antibodies in amyloid-beta oligomer ELISAs. J Alzheimers Dis. 2010;21:1295-301.

78. Magnusson K, Sehlin D, Syvanen S, Svedberg MM, Philipson O, Soderberg L, Tegerstedt K, Holmquist M, Gellerfors P, Tolmachev V, et al. Specific uptake of an amyloid-beta protofibril-binding antibody-tracer in AbetaPP transgenic mouse brain. J Alzheimers Dis. 2013;37:29-40.

79. Sollvander S, Ekholm-Pettersson F, Brundin RM, Westman G, Kilander L, Paulie S, Lannfelt L, Sehlin D. Increased Number of Plasma B Cells Producing Autoantibodies Against Abeta42 Protofibrils in Alzheimer's Disease. J Alzheimers Dis. 2015;48:63-72.

80. Davis AA, Temple S. A self-renewing multipotential stem cell in embryonic rat cerebral cortex. Nature. 1994;372:263-6

81. Ravin R, Hoeppner DJ, Munno DM, Carmel L, Sullivan J, Levitt DL, Miller J Athaide C, Panchision DM, McKay RD. Potency and fate specification in CNS stem cell populations in vitro. Cell Stem Cell. 2008;3:670-80.

82. Lord A, Philipson O, Klingstedt T, Westermark G, Hammarstrom P, Nilsson KP, Nilsson LN. Observations in APP bitransgenic mice suggest that diffuse and compact plaques form via independent processes in Alzheimer's disease. Am J Pathol. 2011;178:2286-98.

83. Stenh C, Englund H, Lord A, Johansson AS, Almeida CG, Gellerfors $P$, Greengard P, Gouras GK, Lannfelt L, Nilsson LN. Amyloid-beta oligomers are inefficiently measured by enzyme-linked immunosorbent assay. Ann Neurol. 2005;58:147-50.

\section{Submit your next manuscript to BioMed Central and we will help you at every step:}

- We accept pre-submission inquiries

- Our selector tool helps you to find the most relevant journal

- We provide round the clock customer support

- Convenient online submission

- Thorough peer review

- Inclusion in PubMed and all major indexing services

- Maximum visibility for your research

Submit your manuscript at www.biomedcentral.com/submit 